\title{
SANDRA ÁLVAREZ HERNÁNDEZ
}

\section{Paisajes oníricos \\ La búsqueda de Polifilo \\ en los jardines del Renacimiento}

Tal vez deberíamos contentarnos con afirmar que en la vida del alma, el pasado puede ser conservado, y no debe necesariamente ser destruido.

Sigmund Freud, El malestar en la civilización

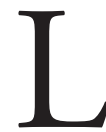

a tradición bibliófila ha nombrado a la Hypnerotomachia Poliphili el más bello libro del Renacimiento. Encontramos el retrato de las numerosas instraciones de la Hypnerotomachia en diversas obras de arte hasta nuestros días. Sin embargo las consideraciones acerca de dónde buscar la celebrada belleza de la obra siguen siendo diversas. Los estudios difieren en sus opiniones; para algunos las I7 I xilografías originales no ostentan un gran manejo de arte, ${ }^{\mathrm{I}}$ para otros el lenguaje en que está escrita originalmente la vuelven de difícil acceso, ${ }^{2}$ o el contenido "novelesco" es pobre, por no decir aburrido, ${ }^{3}$ y si bien, se ha mencionado el cuidadoso trabajo de impresión realizado por Aldo

I. Liane Lefaivre, Leon Battista Alberti's Hypnerotomachia Poliphili (Cambridge y Londres: MIT Press, 1997).

2. Giovanni Pozzi, Francesco Colonna et Alde Manuce (París: Societé Anonyme Monotype, 1962).

3. Jacques Guillaume Legrand, Le Songe de Poliphile (París: P. Didot, I804), 4; Lefaivre, Leon Battista Alberti's Hypnerotomachia Poliphili, 9. 
Manuzio, las miles de erratas contenidas en el texto la ponen en duda. ${ }^{4}$ Entonces, ¿dónde encontrar la más clara belleza del Renacimiento?

El presente trabajo propone el cuidadoso análisis del contenido del Sueño de amor y lucha de Polifilos a fin de develar la fuente de su innegable belleza. La investigación busca mostrar cómo ésta permeó en el mundo de las representaciones oníricas de los jardines del Renacimiento, reflejo de las ilusiones de su época. Los más profundos anhelos de los humanistas italianos y su exploración espiritual en la filosofía griega serán el vehículo de esta búsqueda.

Esta investigación parte de la lectura de la Hypnerotomachia en su lenguaje original. Para todos los extractos aquí citados se elaboró una traducción propia, así como de los textos latinos y griegos referidos.

\section{La vida de Polifilo mediante sus ediciones}

La primera imprenta en tierras latinas existía desde 1465 , fundada por dos alemanes en el monasterio benedictino de Santa Escolástica. ${ }^{6}$ El primer libro ilustrado apareció en 1467 en Roma bajo la firma de una prensa alemana: Las Meditaciones de Turrecremata (fig. I), 7 y en I 472 en Verona una edición de De Re Militari de Robertus Valturius inauguró la tradición de la imprenta italiana (fig. 2). A partir de este momento, y hasta I500, numerosas obras literarias acompańadas de imágenes aparecieron en ciudades como Florencia, Milán y, principalmente, Venecia. Más de una veintena de libros ilustrados se puede contar antes de la aparición de la Hypnerotomachia, sin embargo, ésta representa la cúspide del desarrollo de una técnica, o la mezcla de varias, ${ }^{8}$ a lo largo de

4. Giovanni Pozzi et Lucia Ciapponi, Hypnerotomachia Poliphili (Padua: Atenore, 1968).

5. Propongo esta traducción para la Hypnerotomachia, en lugar de la tradicional, ya que así las tres raíces griegas que se encuentran en su nombre, sueño, amor y lucha, están presentes.

6. Alfred W. Pollard, Italian Book Illustrations (Londres: Seeley and Co. Limited, I894), I7.

7. Pollard, Italian Book. Las 33 ilustraciones que acompañan este texto son la adaptación de los frescos que se encontraban en la capilla de Santa María de Minerva en Roma y que seguramente apoyaban el discurso de las misas, razón por la cual puede haber resultado importante para su autor añadirlas al texto.

8. El arte de la imprenta implica diversas técnicas, desde la fabricación de papel, el trabajo de carpintería y el diseńo de imágenes, hasta la delicada labor de prensar literalmente, folio por folio, cada página de la obra. 


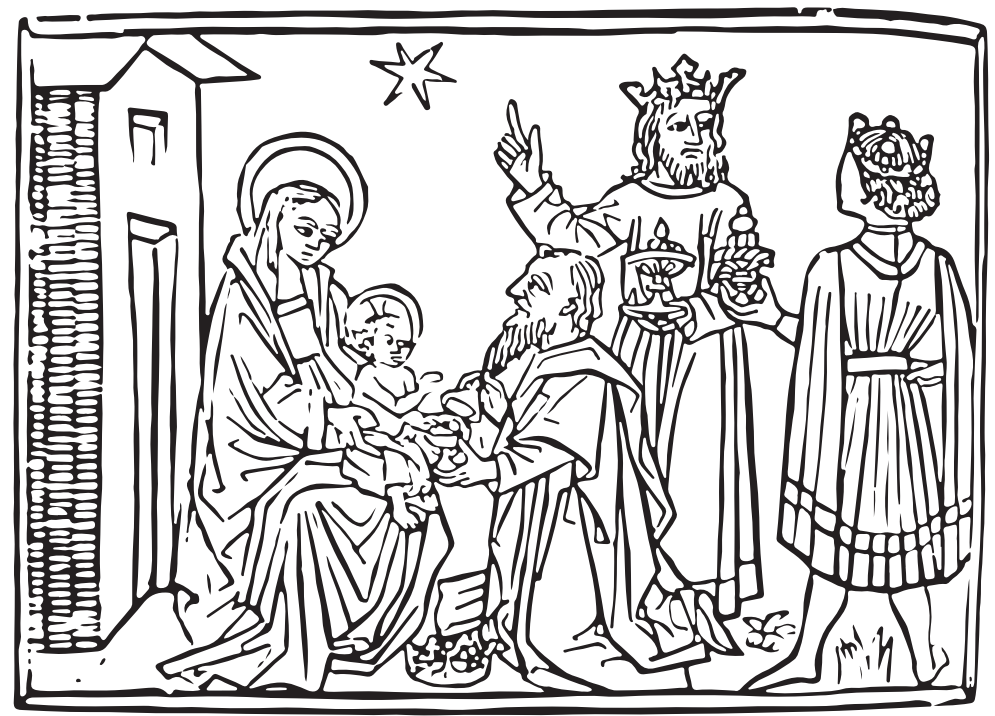

I. Turrecremata, Meditaciones, I467, fol. 4b: "La visita de los Magos”. Biblioteca Nacional de Francia.

2. Roberto Valturius, De Re Militari, I 472, fol. I67v. Library of Congress.

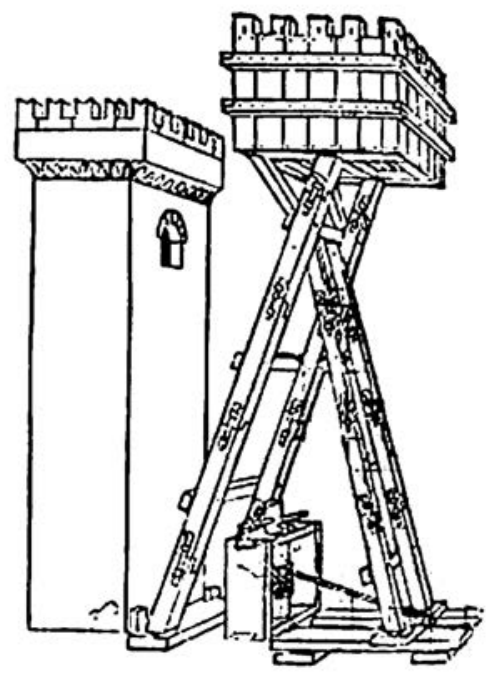


décadas. Además la Hypnerotomachia puede considerarse con justicia el primer libro de arquitectura impreso en compañía de ilustraciones. ${ }^{9}$

Vio la luz en diciembre de I 499 en los talleres de Aldo Manuzio en Venecia bajo el título Hypnerotomachia Poliphili. Ubi omnia humana non nisi somnium esse ostendit, atque obiter plurima scitu sanequam digna commemorat, ${ }^{\mathrm{IO}}$ como aparece en su portada. Este largo título debió resultar difícil de memorizar incluso para sus creadores, porque más tarde en la página ocho, tras las dedicatorias, presentaciones y demás formalidades de los libros de la época, el título se vuelve a repetir pero con algunos cambios. Se lee Poliphili Hypnerotomachia, o sea, el genitivo posesivo antes del nombre al que hace referencia, invirtiendo el uso clásico latino, y también, la conjugación perifrástica esse docet cambia por esse ostendit. Dos detalles que si bien no modifican el sentido de la oración, ${ }^{\mathrm{II}}$ invitan a pensar que ambos folios debieron elaborarse en diferentes momentos, prueba de la gran labor que la creación de un libro como éste debió requerir (fig. 3).

Este cuidadoso trabajo se puede contemplar en sus 467 páginas $^{\mathrm{I2}}$ de elegante acomodo tipográfico y múltiples ornatos, como lo son las 38 letras capitulares adornadas con grutescos, enramados o enlazados (fig. 4a y b). ${ }^{\mathrm{I3}}$ A esto hay que sumar las I6I xilografías que ilustran el texto, de las cuales algunas ocupan una página entera, mientras que otras se insertan de manera elegante entre los párrafos del discurso. No sabemos quién es el autor de estas imágenes; se ha querido identificar a los grandes talentos de la época como Mantegna y Rafael con su creación, entre una larga lista, pero no son más que suposiciones.

9. Lefaivre, Leon Battista Alberti's Hypnerotomachia Poliphili, ro.

Io. El sueño de amor y lucha de Polifilo. Donde se muestra que todas las cosas humanas no son sino sueño, y de paso se recuerdan muchas cosas verdaderamente dignas.

I I. Ambos verbos pueden traducirse por mostrar, aunque a doceo se le da tradicionalmente un sentido más pedagógico, como instruir o enseñar, mientras que ostendit suele traducirse como presentar o exponer.

I2. No están numeradas todas las páginas, pero tomando como guía los pocos folios en que aparece alguna marca, considero que la manera correcta de contarlas es con números arábigos del I al 7 las páginas introductorias; el primer libro con caracteres latinos en minúsculas de la "a" a la "z" contando ocho hojas con números romanos, de los cuales aparecen los primeros como a i, a ii, y a iii; y caracteres latinos en mayúsculas para los I3 capítulos, con folios numerados para el segundo libro.

I3. Treinta y siete forman el célebre acróstico y la primera se encuentra en las palabras dedicadas a Polia antes del inicio del Sueño. 


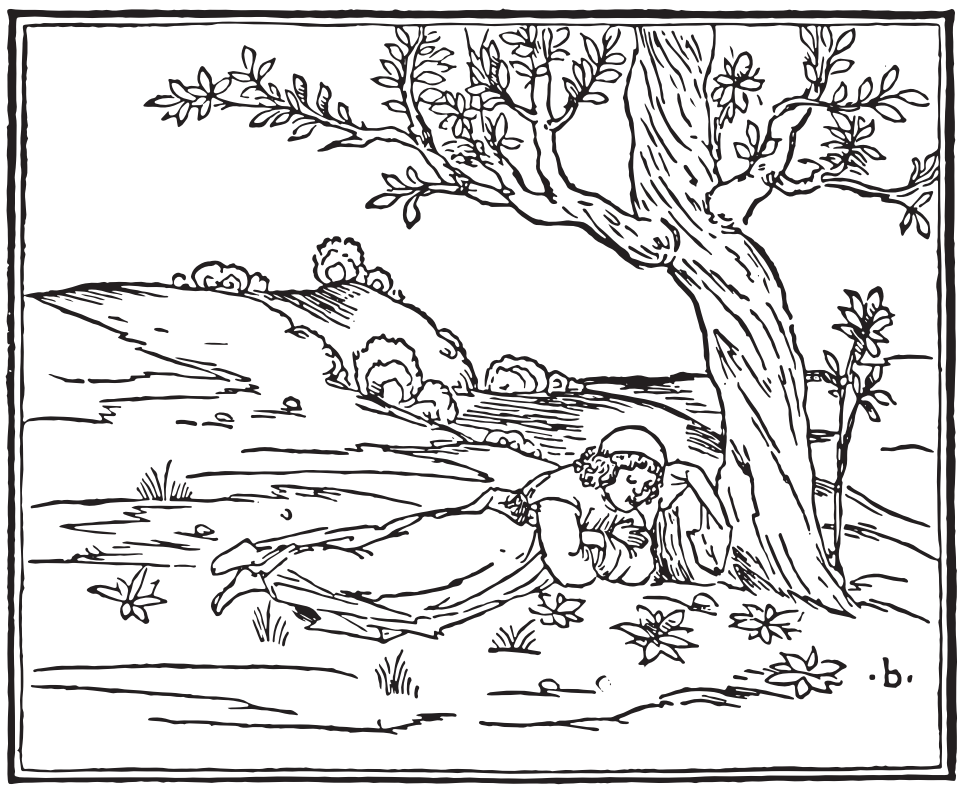

3. Grabado de la edición aldina, Hypnerotomachia Poliphili, I499, tomado de Francesco Colonna, Hypnerotomachia Poliphili. The Strife of Love in a Dream, trad. e introd. Joscelyn Godwin (Londres: Thames and Hudson, 1999), 20.

La única certeza es que fueron realizados en algún taller veneciano, representante de la época. ${ }^{14}$

I4. J.G. Legrand en su Songe de Poliphile los atribuye a Mantegna, 5; Perrini en Notes sur l'edition originale les premieres éditions et les traductions en la reimpresión de la Bibliothèque Municipale d'Auxerre de la edición de 1546, menciona a Rafael Sanzio, Giovanni Bellini, Carpaccio y Mantegna, XXV. Eugène Piot añadió el nombre del "maestro del delfín", el mismo que diseñó la famosa ancla con un delfín, sello de la imprenta de Manuzio, y Claudio Popelin en su edición apoya esta iniciativa, CXCIX. Scapecchi en su artículo "Continuità del Polifilo", publicado en ocasión de la exposición Un libro in mostra en Spezia en el 200I, nombró al taller de Benedetto Bordon, I8. Charles Ephrussi afirma que es inútil querer atribuirlos a un nombre famoso, simplemente hay que reconocer que el ilustrador de Polifilo puede ser llamado primus inter pares con justicia, en la 3i de su Étude sur le Songe de Poliphile publicado en 1888 . W. Griggs acepta sin comentarios que pertenecen a la escuela veneciana en su publicación facsimilar de I888, 3. En cambio para Pozzi, dada la importante relación que guardan el texto y la imagen en el libro, es evidente que Colonna mismo debía haberlos realizado, Hypnerotomachia Poliphili, I2-ss., mientras que Lefaivre reconoce este 
a)

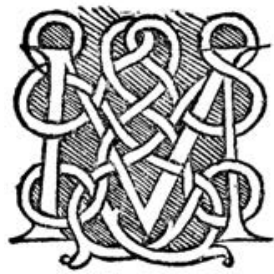

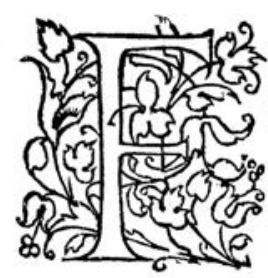

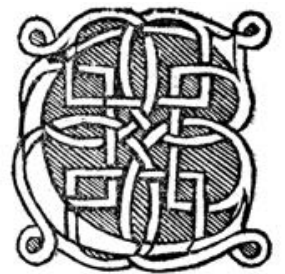

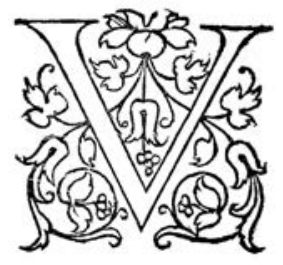

b) POLIPHILI HYPNEROTOMACHIA, VBI HVMANA OMNIA NON NISI SOMNIVM ESSE OSTENDIT,AT QVE OBITER PLVRIMA SCITV SANEQVAM DIGNA COMMEMO,, RAT.

***

*

4. a y b) El trabajo de la edición aldina, Hypnerotomachia Poliphili, I499. Biblioteca Nacional de Francia.

A la belleza de este libro se ańade el secreto de su autor, enunciado de manera elegante en los siguientes versos de Andrea Maro Brixanus que anteceden a la obra:

—Dime, Musa, ¿̇e quién es esta obra?

- Mía y de mis ocho hermanas.

- ¿Vuestra? ¿Entonces por qué le dan el nombre de Polifilo?

—Lo mereció por ser común alumno de todas nosotras. ${ }^{\text {Is }}$

vínculo, pero acepta que si bien el mismo autor las ideó, su realización fue relegada a alguien más, Leon Battista Alberti's Hypnerotomachia Poliphili, I3I. Éstas son sólo algunas de las numerosas propuestas a las que sería inútil procurar darles algún orden, ya que han cambiado sin tendencia ni concierto.

I5. "Cuius opus dic, Musa? -Meum est octoque sororum.- Vestrum? Cur datus est Poliphilo titulus?-Plus etiam a nobis meruit communis alumnus.- ", Poliphili Hypnerotomachia. Ubia omnia humana, 7. 
En el acróstico que forman las letras capitulares de sus treinta y siete apartados se lee: Poliam Frater Francescus Columna Peramavit. ${ }^{16}$ Por las noticias que tenemos podemos suponer que fue un código prontamente develado. ${ }^{17}$ No debe extrańarnos, ya que este tipo de adornos no era del todo desconocido, al contrario, era una moda inaugurada hacía siglos. ${ }^{18}$ Pensar que éste era un verdadero intento por ocultar el nombre del autor, podría resultar ingenuo; el acróstico pudo resultar antes que nada otro ornato para este elegantísimo libro. En lo que respecta a la autoría, lo único que sabemos es que el creador de este texto, así como el de sus grabados, sigue siendo incierto hasta nuestros días. Esta edición es sin duda una preciosa joya, misma que sus creadores consiguieron exitosamente proteger con el más hermoso velo de misterio.

Sin embargo, el éxito de la obra no fue instantáneo. Leonardo Grasso, su patrocinador, encontró difícil su venta. En febrero de 1509 declaró que a pesar de su "grandísima elegancia", por los tiempos y disturbios de la guerra aún conservaba casi todas las copias. ${ }^{19}$ Pero la fortuna de la obra cambió prontamente a la muerte de Grasso, en I536, cuando los hijos de Manuzio comenzaron la preparación de una segunda edición. Además, la buena recepción de la Hypnerotomachia en el siglo XVI se puede observar en las numerosas obras de arte que inspiró, así como en los jardines y palacios que buscaron retratarla. Para acentuar este nuevo aire de éxito, la primera edición francesa se publicó en I546, sólo un año después de la segunda impresión italiana. ${ }^{20}$

I6. "El hermano Francesco Colonna amó mucho a Polia", en Poliphili Hypnerotomachia. Ubi omnia humana non nisi somnium esse ostendit, atque obiter plurima scitu sanequam digna commemorat (Venecia: Aldi Manutii, I499).

I7. En su nota a la primera edición francesa Jean Martin da noticia de ello, sin embargo, no transcribe la frase, prefiriendo guardar el misterio, así como en lugar de dar el nombre que se daba a la verdadera Polia escribe "le nom de la Romaine qui se tua pour avoir esté violee...”, sig. â iij. Jacques Gohorry en su nota a la segunda edición compara este motivo a aquel utilizado por el constructor del faro de Alejandría; también véase G. Perrini, Notes sur l'edition originale, XXIII.

I8. G. Perrini, Notes sur l'edition originale, XXIII; Legrand, Le Songe de Poliphile, 4, y Ernst Robert Curtius, Literatura Europea y Edad Media Latina (México: Fondo de Cultura Económica, 1955), 397-ss.

19. Scapecchi, Un libro in mostra, I8; Lang, The Strife of Love in a Dream, XIV.

20. Los ańos que pasaron entre la muerte de Grassi y esta segunda publicación se deben a los trámites que los hijos de Manuzio debieron llevar a cabo para el permiso de su realización, así como la elaboración de algunas nuevas planchas cuyos originales probablemente se encontraban dañados. 
El libro que imprimieron los hijos de Manuzio es, de manera general, igual al anterior, salvo por algunas modificaciones. Primero, se nota la ausencia de la fe de erratas que aparecía al final de la primera edición, muestra de que las correcciones se hicieron. Después, el título latino se tradujo al italiano ${ }^{21} y$, finalmente, algunos grabados fueron reelaborados, ${ }^{22}$ como el Pegaso con putti y Polifilo con cinco ninfas; ${ }^{23}$ este último destaca por la evidente brusquedad de su trabajo. Sin embargo, lo más notorio es la falta de las elaboradas letras capitulares, en cuyo lugar encontramos un vacío. Tras el surgimiento de la imprenta los manuscritos elaborados y decorados a mano perdieron posición en el mercado de libros, empero, sus adornos permanecieron en el gusto del público por algún tiempo. Razón por la cual algunas imprentas decidían deliberadamente, en los libros de fino trabajo, dejar el espacio en el que después se pudiera dibujar a mano con tintas de colores los márgenes y las letras capitulares. ${ }^{24}$ Imagino que es el caso de esta edición cuyo fino papel con filo de oro resalta en comparación al anterior, y que se ajusta a la exquisita presencia de todas las ediciones de esta obra en la historia.

La edición francesa tiene un origen no menos misterioso que el italiano. Apareció en la imprenta de Jacques Kerver en París, dedicada al honor de Enrique II, bajo el cuidado del célebre humanista Jean Martin. Al estudioso se debe la primera traducción de Vitrubio al francés, pero no así la de la Hypnerotomachia. Martin asienta en su introducción haber recibido el manuscrito de manos de un amigo quien lo había obtenido de un gentilhombre, y que si bien no se trataba de un "Cicerón francés", es digno de admiración. ${ }^{25}$ El traductor desconocido logró cambiar un lenguaje que ni los italianos entendían por un francés de uso común en la época. Por su parte, Martin notó que no se trataba más que de una versión incompleta y poco fiel del original, pero las correcciones que le hizo fueron menores, sólo con la intención de volver su lectura más sencilla. ${ }^{26}$ En la segun-

21. La Hypnerotomachia di Polifilo, cioè pugna d'amor in sogno dov'egli mostra che tutte le cose humane son sono altre che sogno et dove narra molt'altre cose digne di cognitione (Venecia: in casa de figlivoli di Aldo, I545).

22. Piero Scapecchi cuenta siete notorios por la brusquedad de su trabajo, y Giovanni Pozzi, ocho.

23. Signaturas b 4 y e 2.

24. Pollard, Italian Book Illustrations, chiefly of the Fifteenth Century, I4.

25. Ephrussi piensa que el mismo Martin pudo haber realizado la traducción completa y por alguna razón incierta haber decidido ocultarlo, Étude sur le Songe de Poliphile, I9.

26. En la edición de I554, sig. ã iij; en Legrand, Le Songe de Poliphile, 202. 


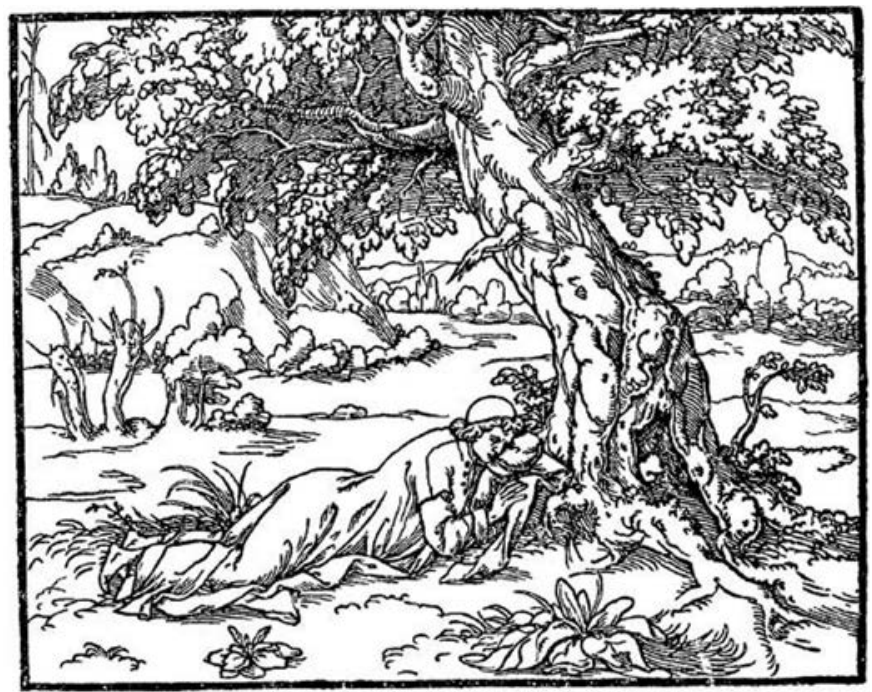

5. Grabado de la edición francesa, Le Songe de Poliphile, I546.

Biblioteca Nacional de Francia.

da impresión francesa se añade un comentario de Jacques Gohorry, el supuesto amigo de Martin, que refrenda la versión, sin develar la identidad del traductor dándole el título de noble caballero de Malta. ${ }^{27}$ Así la recepción del siglo Xvi se caracterizó por el secreto que envolvía la génesis de la obra y la oculta fuente de sabiduría, ya fuera de su autor o su traductor.

Esta edición también cuenta con I83 planchas originales, de las que I6I son copias del original italiano, con algunos detalles añadidos y otros excluidos, conforme al gusto de su autor (fig. 5).

Doce nuevas imágenes pretenden completar los huecos de la primera edición, ${ }^{28}$ y también éstas, como las italianas, no están acompañadas del nombre de su creador. Entre los probables realizadores se nombra, tomando en cuenta la similitud del trabajo con sus ilustraciones de l'Entrée de Henri II à Paris, ${ }^{29}$ a Jean Cousin. Se menciona también, más ampliamente aceptado, al

27. Edición de 1554 , XXIX-XXX.

28. Dentro del discurso de Polifilo se realiza la descripción de algunos diseños que no aparecen en las ilustraciones a pesar de que el mismo narrador remita a ellos.

29. Perrini, Le Songe de Poliphile, XXXII; Polizzi, Le Songe de Poliphile, XXII. 
amigo de Martin, Jean Goujon (fig. 6), ilustrador de su Vitrubio, como el más probable autor de las arquitecturas polifilescas. ${ }^{30}$

Esta misma presentación de la Hypnerotomachia apareció en otras dos ocasiones, una en I554 y otra en I56I, en la imprenta de Kerver, con el único añadido de la nota de Gohorry que ya comentamos. A éstas sigue la primera edición inglesa de 1592, incompleta y poco fiel a su original, sólo contiene los primeros 24 libros y 25 nuevas ilustraciones de pobre trabajo (fig. 7). Está dedicada a Sir Philip Sidney y existen pocos ejemplares. La traducción no muestra ningún despliegue de sabiduría ni por el uso del lenguaje ni por su interpretación del original, aspecto que queda manifiesto desde las primeras líneas. En la presentación sólo aparecen las iniciales del traductor: R. D., hoy reconocido como Robert Dallington, un maestro de escuela que también publicó un libro sobre la Toscana, del que no se tiene mayor noticia. ${ }^{31}$ No obstante, creo que la fama de Polifilo en aquellas tierras no debió ser poca, ya que se tradujo en diversas obras de arte plástico e incluso en la literatura. El mismo William Shakespeare escribió un poema titulado "The Passionate Pilgrim", que tiene íntima relación con la obra que nos ocupa, aunque tal vez nos es lícito pensar que la conoció por medio de su edición francesa o italiana. De hecho se tiene el dato de que la biblioteca del dramaturgo Ben Jonson incluía un ejemplar veneciano de $1545{ }^{32}$

Francia fue de nuevo el escenario para el surgimiento de otra edición en I600. Trabajo de Beroaldo de Verville, con un nuevo título, Le Tableau des riches inventions, couvertes $d u$ voile des feintes amoureuses, qui sont représentées dans le songe de Poliphile... (fig. 8), ${ }^{33}$ es una versión fiel a la traducción del caballero de Malta con algunos añadidos y cambios, no siempre apegados al original latino, sino a la imaginación de su creador. Por ejemplo, ya que se muestra consciente de que toda traducción no puede ser más que una imitación, ha cambiado el inicio de cada capítulo para recordar el acróstico italiano con la frase:

30. Legrand, Le Songe de Poliphile, 5; Perrini, Le Songe de Poliphile, XXXI.

31. Olga Zorzi, "English Translations from the Italian Humanists: An Interpretative Survey and Bibliography”, Italica 59, núm. 3, Italian Literature in English Translation (Autumn, I973): 408-434, especialmente 4I5.

32. Michael Leslie, "The Hypnerotomachia Poliphili and the Elizabethan Landscape Entertainments", Word \& Image I4 (I/2) (January-June, I998): I30-I44, especialmente I3I.

33. Le Tableau de riches inventions, couvertes du voile des feintes amoureuses, qui sont représentées dans le songe de Poliphile. Desvoilées des ombres du songe, et subtilement exposées par Béroalde (París: chez Matthieu Guillemot, I600). 


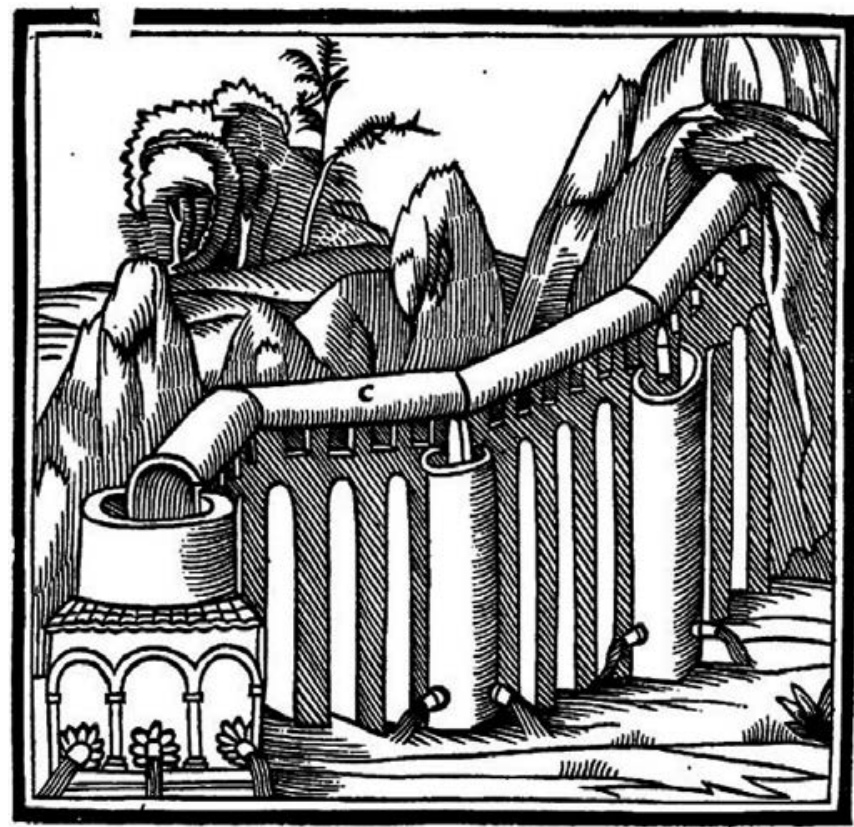

6. Marc Vitruve Pollion, Architecture ou Art de bien bastir de Vitruve, con dibujos de Jean Goujon, I553, unesco. The Internet Archive/archive.org

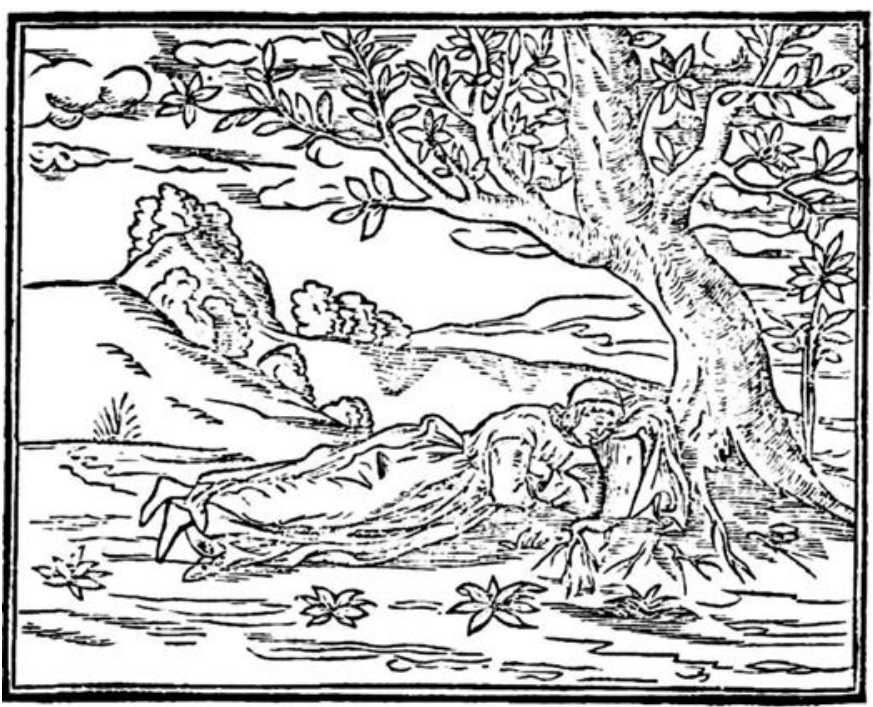

7. The Strife of Love in a Dream (Londres, I592). Biblioteca Nacional de Francia. 


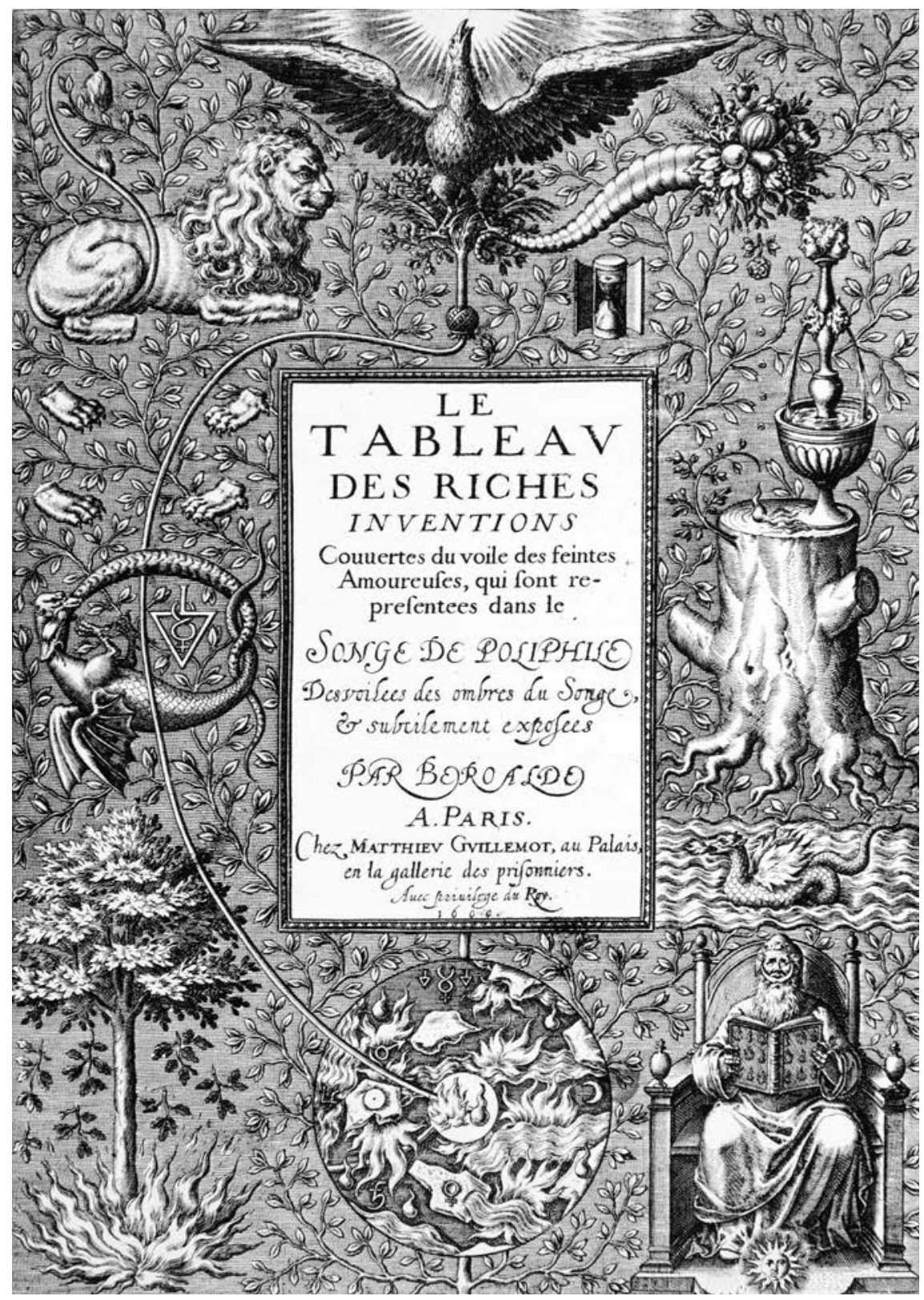

8. Le Tableau des riches inventions, Beroaldo de Verville (París, I600), tomada de Stanislas Klossowski de Rola, The Golden Game. Alchemical Engravings of the Seventeenth Century (Londres: Thames and Hudson, 1988), 26. 
"François Colomne serviteur fidele de Polia", ${ }^{34}$ misma que encuentra más adecuada para un gentilhombre. ${ }^{35}$

En la introducción que dedica Beroaldo a "los bellos espíritus que posen sus ojos sobre estos serios asuntos de placer", ${ }^{6}$ se especula sobre la naturaleza del autor quien debió ser un filósofo, un alquimista, un sabio: alguien versado en los más diversos misterios. A este comentario le sigue un Recueil Steganographique contenant l'intelligence au frontispice, ${ }^{37}$ en el que el autor más allá de develar ningún misterio, añade un acertijo a la obra. La portada del libro consiste en el tableau que pretende desvanecer las sombras del Sueño y así exponerlas sutilmente. Es un bello grabado compuesto por un frontispicio decorado con diferentes figuras, todas típicos símbolos de la ciencia alquímica, a la cual el nuevo editor era sin duda afín. La descripción está elaborada a modo de un sueño, claramente imitación del de Polifilo, en el que aparecen los elementos del frontispicio y se les da una pequeña explicación. A pesar de que esta descripción es testimonio de una nueva lectura de la obra que refrenda su origen de sabiduría antiquísima y subraya su belleza hablando en su mismo lenguaje, para los estudios modernos, y un público más general, no es más que otro enigma a revelar. A ésta le seguiría una edición también francesa aparecida en 1772 mencionada en algunas notas y bibliografías, pero de la cual no se encuentra mayor noticia, probablemente se trate de una simple reimpresión de esta última.

En I804 apareció la versión también francesa de Jacques Guillaume Legrand que si bien los estudios posteriores han considerado no digna de tomarse en cuenta, me parece un testimonio de lo más interesante. Desde la portada se nos anuncia que se trata de una traducción libre. Para comprender qué tono tomará esta libertad no hace falta más que leer la interpretación que se da al título en griego: "Combate del Sueño y del Amor", siendo Polifilo "el amante de Poli o Polia" ${ }^{38}$ Bien informado, tras un estudio de las ediciones anteriores, el autor anuncia que no ha encontrado otra manera más que intentar una "traducción libre", o más bien, una "imitación”, y hasta añadir algo o extenderse en algu-

34. La traducción del caballero de Malta respeta el orden del original italiano.

35. De Verville, Le Tableau de riches inventions, 8 (digital).

36. De Verville, Le Tableau de riches inventions, 6 (digital).

37. "Recopilación esteganográfica que contiene la inteligencia del frontispicio". La palabra steganographique viene del griego steganós, que quiere decir oculto y grafé escritura. El término fue acuñado desde 1499 por Johannes Trithemius para su volumen Steganographia que trata de magia.

38. Legrand, Le Songe de Poliphile, 2. 
na idea original. ${ }^{39}$ Asimismo ha decidido comenzar cada capítulo indicando con una sola palabra la situación de los personajes, no una frase como establecía la tradición, ${ }^{40}$ y respetando la primera letra del contenido, ya que el acróstico tenía gran importancia para $s u$ entendimiento de la obra. ${ }^{4 \mathrm{I}}$ Finalmente después de presentar su traducción a los dos libros, termina el segundo volumen con algunas "Observaciones", ya que el lenguaje original de Polifilo se encontraba cifrado, unos comentarios a las traducciones le parecen necesarios. Un poco más adelante el autor se permite justificar algunas de las modificaciones al texto. Por ejemplo, Polia es bella, sabia y virtuosa, por lo que le pareció bien conservar su carácter, pero al contrario en el caso de Polifilo, al tratarse de un "llorón insoportable", ${ }^{42}$ se vio en la necesidad de cambiarlo un poco, suprimiendo así sus constantes suspiros y llantos. Asimismo, se permitió modificar algunas de las detalladas descripciones del Sueño a fin de volverlas "más aptas a los principios del buen gusto". ${ }^{43}$ Sobresale de esta edición el hecho de no estar acompañada de ninguna imagen.

Resulta evidente que Legrand, "arquitecto de monumentos públicos y miembro de numerosas sociedades de sabiduría y literatura”, se encontraba influenciado por el romanticismo de Johann Joachim Winckelmann y otros pensadores de la época. No hay que olvidar que el trabajo de edición e impresión de un libro implica a más de una persona y varios intereses, así que podemos reconocer la obra de Legrand como el reflejo del espíritu del momento. No obstante el tono de la comprensión teórica del texto, la imagen de la Hypnerotomachia está presente en la obra plástica contemporánea, como es el caso de la arquitectura de Claude-Nicolas Ledoux. ${ }^{44}$

En I883 encontramos la primera traducción completa, 45 así como la primera edición académica del Sueño elaborada por Claudio Popelin con nuevas

39. Legrand, Le Songe de Poliphile, 4. Por ejemplo, al pasaje en el que Polifilo visita el cuerpo de un coloso yacente y después observa uno femenino sin acercarse a él, se dio el gusto de extenderse en una fantasía de su ocurrencia: la anatomía femenina se encontraba rodeada de unos obstáculos imposibles de sortear.

40. Legrand, Le Songe de Poliphile, 9.

4I. Las traducciones anteriores habían respetado el mismo orden del italiano.

42. Legrand, Le Songe de Poliphile, 176.

43. Legrand, Le Songe de Poliphile, I76-178.

44. Paul V. Turner, "Claude-Nicolas Ledoux and the Hypnerotomachia Poliphili", Word \&. Image I4 (1998): 203-2I4.

45. Literalmente traducida asienta su autor, y es la primera en finalizar con el Epitafio de Polia, desconocido hasta el momento en las ediciones francesas. 
ilustraciones de Alfred Prunaire en París. Antecede al discurso una larga introducción de 237 páginas ya que a Popelin "no le pareció inútil describir el avance de la cultura italiana a través de la Edad Media hasta llegar al momento de Francesco Colonna". ${ }^{6}$ Las xilografías, aunque se declara su renovación, son prácticamente idénticas a las anteriores excepto el diagrama de la gran puerta bajo la pirámide y el plano de la isla de Cythera que tienen un par de detalles diferentes.

En I 888 apareció una recolección de las I68 xilografías, y I5 letras capitulares, de la Hypnerotomachia sin texto, sólo acompañadas de una nota introductoria y descripciones por W. Griggs. La noticia introductoria es breve, trata sobre el libro, su autor y sus traducciones y ediciones sin proponer nada nuevo. Narra la trama del Sueño sin haberlo leído, es evidente que Griggs reconstruyó la historia a partir de las ilustraciones ya que, por ejemplo, piensa que el sueño comienza cuando Polifilo cae dormido bajo la sombra de unos árboles. Más adelante dedica un par de párrafos a la admiración, perplejidad y rechazo provocados en torno a Polifilo. En particular, no encuentra ninguna proeza literaria en ella, como era de esperarse de una presentación sin texto.

En 1890 en Londres, David Nutt publicó una nueva edición al cuidado de Andrew Lang. El texto es la misma traducción "ignorante e ininteligible", como la califica el propio Lang, ${ }^{47}$ de la primera publicación. En cambio, en lugar de las ilustraciones inglesas aparece una selección de las originales italianas. Esta presentación realmente no resulta de ningún interés para el estudio de la obra, a no ser por una pequeña narración de Lang que antecede al libro. Cuenta cómo por 20 chelines compró una edición usada en malas condiciones de un libro llamado Hypnerotomachia. The Strife of Love in a Dream, impresa en 1592 por Simon Waterson para ser vendida en su tienda en S. Paules Churchyard. No tenía el nombre de ningún autor o traductor y era en sí un volumen imperfecto. Lo hojeó algunos días y habiendo saciado su interés por él, bajo la excusa de la ausencia de las últimas cinco páginas, lo cambió al vendedor por un ejemplar de Les Memoires de la Reyne Marguerite de i66r. Más tarde este mismo despreciado ejemplar lo compraría por "un precio de ésos que

46. Claudio Popelin, Le Songe de Poliphile ou Hypnerotomachia de Frère Francesco Colonna littéralement traduit pour la première fois avec une introduction et des notes (París: I. Liseux, I883), IX.

47. Andrew Lang, The Strife of Love in a Dream. Being the Elizabethan version of the First Book of Hypnerotomachia Poliphili of Francesco Colonna, a new edition (Londres: David Nutt in the Strand, I890), VII. 
uno no puede rechazar" ${ }^{48}$ Claudio Popelin, quien se encontraba preparando su volumen, a tiempo para que Lang cayera en la cuenta del infortunio que cometió al haber cambiado uno de los libros más raros del mundo por las Memorias de una reina. ${ }^{49}$ Entonces Lang estimó correctamente que no era probable que para nadie resultara valioso traducir de nuevo la Hypnerotomachia al inglés, y ciertamente, la primera traducción completa no apareció hasta 1999. Entre tantas vicisitudes el editor no deja de apreciar el alto valor de esta obra ya que "la vida, como es, puede no ser perfecta, pero es más valiosa en la manera en que los visionarios la recrean, y, por lo menos, podemos saborear y disfrutar moderadamente toda clase de ideales en ese mundo, la isla de los sueños". 50

A las ediciones aquí apuntadas siguen al menos otra docena, muchas de las cuales son sólo reimpresiones y ediciones facsimilares de las ya existentes. Quisiera destacar entre todas, aquélla a cargo de Giovanni Pozzi y Lucia Ciaponni publicada en Padua en 1968. Ésta es la primera transcripción completa del texto, tal y como aparece en el original aldino, en tipografía moderna. Es, en efecto, la primera edición crítica elaborada del Sueño y el primer paso para todo estudio serio sobre el mismo. A este esfuerzo sigue más tarde, la edición crítica del Songe francés elaborada por Gilles Polizzi en 1994. A la publicación de Pozzi antecede otra de 1959 a cargo de él mismo y de Maria Teresa Casella sobre Francesco Colonna, su obra y su vida. Considero que estas publicaciones inauguran la recepción contemporánea de la Hypnerotomachia. Más tarde en 1983 aparecería la publicación de Maurizio Calvesi Il Sogno di Poliphilo prenestino, en la cual presenta su propuesta para la autoría del Sueño, desatando así una viva disputa académica hasta nuestros días. Si bien esta discusión ha inspirado a los autores a profundizar sus estudios incesantemente, la cuestión es en absoluto irrelevante para este trabajo. Desentrañar la identidad del autor de la Hypnerotomachia, ya sea el monje dominico, ${ }^{5 \mathrm{I}}$

48. En el original "à un de ces prix qu'on n'avoue pas à sa ménagère", en Lang, The Strife of Love in a Dream, VII.

49. Lang, The Strife of Love in a Dream, VI-VII.

50. "For life, as it is, may not be perfect, but it is more endurable than life as visionaries would remake it, and least, we can taste and moderately enjoy all ideals in this world, the isle of dreams", Lang, The Strife of Love in a Dream, XVII. Para la bibliografía extensa consúltese Sandra Álvarez Hernández, "Pasajes oníricos. La búsqueda de Polifilo en los jardines del Renacimiento”, tesis de Maestría (México: Universidad Nacional Autónoma de MéxicoFacultad de Filosofía y Letras, 2012), 59-63.

51. María Teresa Casella e Giovanni Pozzi, Francesco Colonna. Biografia e opere (Padua: Atenore, 1959). 
el señor romano, ${ }^{52}$ Felice Feliciano ${ }^{53}$ o el mismo León Battista Alberti, ${ }^{54}$ no tiene lugar en esta disertación.

En 1998 se realizó un simposio en Óxford en el que se invitó a presentar trabajos que versaran sobre "Garden and architectural dreamscapes in the Hypnerotomachia Poliphili". En esa ocasión ningún trabajo, o sólo de manera incidental en algunos casos, trató sobre la autoría de la obra, en parte por la ausencia del señor Calvesi y en parte por la muy reciente publicación de Roswitha Stewering.55 El caso, como atestigua el volumen I4 de la revista Word \& Image, que publica las ponencias leídas en esa ocasión, es que esta ausencia brindó a las conferencias una fluidez y riqueza refrescantes. Como apunta Michael Leslie en su participación en este evento, la Hypnerotomachia puede ser interpretada en términos culturales como el producto de una época y una sociedad, ${ }^{56}$ idea que creo se puede aplicar a toda gran obra de arte y que me propongo seguir.

En la actualidad Polifilo, lejos de ser un libro extraño y desconocido, se ha vuelto la referencia obligatoria para todo estudio de la cultura del Renacimiento italiano, ya sea a causa de su importancia en la comprensión del arte de la imprenta, la arquitectura o la iconografía. Sólo me resta mencionar las escasas ediciones del Sueño de Polifilo en el mundo hispano. La primera es una edición facsimilar con introducción de Peter Dronke, publicada en Zaragoza en I98I. A ésta le siguen la traducción del Colegio de Arquitectos Técnicos de Valencia y la de los Arquitectos de Murcia, también en 1981. La versión de Zaragoza fue reeditada recientemente por Acantilado en Barcelona en 2008, publicación que, a diferencia de la anterior, presenta las ilustraciones originales. Publicaciones tardías si tomamos en cuenta que probablemente el Sueño brindó nociones de urbanismo a las órdenes mendicantes e inspiró la creación de huertos a lo largo de la Nueva España. ${ }^{57}$ Asimismo, las ilustraciones del sueño parecen

52. Maurizio Calvesi, Il Sogno di Polifilo prenestino (Roma: Officina, I983); Maurizio Calvesi, La "Pugna di amore in sogno" di Francesco Colonna romano (Roma: Lithos, I996).

53. A. Khomentovskaia, Felice Feliciano da Verona comme l'auteur de l'Hypnerotomachia Poliphili (Florencia: Leo O. Olschki, I936).

54. Lefaivre, Leon Battista Alberti's Hypnerotomachia Poliphili; Emanuela Kretzulesco-Quaranta, Los jardines del sueño. Polifilo y la mistica del Renacimiento (Madrid: Ediciones Siruela, 1996).

55. Roswitha Stewering, Architektur und Natur in der "Hypnerotomachia Poliphili" (Hamburgo: Lit, 1996).

56. Leslie, "The Hypnerotomachia Poliphili", Iзо.

57. George Kubler, Arquitectura mexicana del siglo XVI (México: Fondo de Cultura Económica, I983), I04. Al hablar respecto de las inusitadas plazas públicas, las cuales marcaron el 
haber inspirado aquéllas de la Casa del Deán en Puebla, ${ }^{58}$ y en el siglo xx, las famosas Pozas de Xilitla en San Luis Potosí.99 Por tanto, creo que la propuesta de una traducción y edición elaborada por humanistas, y no técnicos, de la Hypnerotomachia en México u otro país latinoamericano es indispensable. Este trabajo propone una traducción propia a los extractos seleccionados del Sueño, partiendo de que debemos su creación a una generación de hombres de profunda formación humanística y a una lectura atenta de la filosofía clásica. El Sueño de amor y lucha de Polifilo es el reflejo de una sensibilidad poco frecuente, que bien apreciada puede mostrarnos, en efecto, que en esta vida todo es sueño.

\section{Los jardines del Sueño}

La Hypnerotomachia ha sido juzgada a lo largo de la historia bajo múltiples criterios: romance amoroso, tratado de arquitectura, compendio botánico, popurrí mitológico y narración erótica, pero su verdadero lugar se encuentra entre sueños. Como su título indica, éste es el recuento de una experiencia vivida dentro un sueño impulsado por el amor y la lucha. ${ }^{60}$ Las palabras erós y maché han sido analizadas en la amplia gama de sus significados por diferentes estudiosos, pero pocos parecen haber notado la relevancia de la palabra hypnós que es mucho más que un simple sueño.

La tradición de la lectura de las experiencias oníricas se remonta a las civilizaciones más antiguas del mundo. Durante el Renacimiento, la tradición clásica, establecida por Artemidoro de Éfeso en la segunda mitad del siglo iI d. C.

plan urbano de los pueblos novohispanos y los huertos que formaban parte de los conjuntos conventuales. Afirmación a la cual le falta un profundo análisis acerca de la existencia de la Hypnerotomachia en las bibliotecas novohispanas.

58. Si bien la información con la que contamos acerca de esta obra y sus propietarios es poca, la semejanza entre los murales conservados y las ilustraciones de la Hypnerotomachia es evidente, y abre una línea de investigación que debiese ser profundizada.

59. En el Libro X de la narración de Polifilo se describe un jardín hecho de cristal desarrollado en algunas pozas de agua que funcionan como una alegoría de la vida, rodeadas de construcciones, como torres que parecen no llevar a ningún lugar, pero funcionan como miradores. Este artificio se asemeja al creado por Edward James en su jardín lleno de simbolismo y magia.

6o. La palabra Hypnerotomachia, acuñada por el autor de la obra, está formada por tres vocablos griegos: hypnós, sobre la cual se hablará y que en términos generales se traduce como sueño, erós, amor y maché, lucha. 
y su obra Oneirokritika ${ }^{6}{ }^{1}$ fue retomada por muchos que hicieron de sus sueños obras de arte maestras, ${ }^{62}$ como el que nos ocupa. También, a partir de los estudios de Sigmund Freud el público ha tomado con mayor seriedad su relevancia, pero no debemos remontarnos tantos siglos adelante para comprender el significado de la visión de Polifilo. ${ }^{63}$ Probablemente entre los sueños más famosos de la historia se encuentre el Sueño de Escipión narrado en el libro VI de la De Re Publica de Marco Tulio Cicerón, siglo i a. C. A su vez, este sueño debe su fama a los Comentarios que más tarde Macrobio desarrolló sobre él, en el siglo IV d. C. De hecho, fundamentalmente gracias a este último texto durante mucho tiempo se supo lo que había escrito el célebre orador romano a falta de una copia completa de la De Re Publica. ${ }^{64}$ Por su parte, los Comentarios de Macrobio superan por mucho la longitud del episodio del sueño y se extienden en toda clase de anotaciones, desde anatomía, geografía y astrología, hasta música, y por supuesto: la tipología de los sueños.

Macrobio distingue en cinco variedades diferentes las visiones que tenemos mientras dormimos: la que los griegos llaman óneiros y los latinos somnium, el hórama o visio, el krematismós u oraculum, el enýpnion o insomnio y el fántasma o visum. Los últimos dos sin cualidades adivinatorias; esta clasificación coincide con la realizada por el griego Artemidoro. En ésta reconocemos en el enýpnion la palabra hypnós que compone la primera parte del nombre Hypnerotomachia. Macrobio la define como aquella visión que aparece cuando alguna preocupación abruma nuestro ánimo, nuestro cuerpo o nuestra fortuna. Entonces el asunto se aparece mientras dormimos tal cual nos había inquietado estando despiertos. Si tenemos un amor, nos vemos o disfrutando o carentes de sus delicias; si es algún miedo, nos vemos a partir de una imagen de nuestros pensamientos, afrontando la situación. Si es nuestro cuerpo el que sufre, nos vemos bajo los efectos del exceso del alimento y la bebida, o al contrario, sedientos y hambrientos. Y finalmente, si es nuestra fortuna la que nos preocupa, aparecemos recibiendo honores y cargos por su deseo, o perdiéndolos por miedo. Esta clase de sueños sólo importan mientras suceden, al termi-

6I. Del griego oneirós y kritikós, es un compendio que brinda las herramientas para juzgar los sueños.

62. Eugenio Battisti, L'antirinascimento (Milán: Feltrinelli, I962), in8.

63. Como hace Lefaivre, Leon Battista Alberti's Hypnerotomachia Poliphili, 46-ss.

64. Apenas en I822 el cardenal Angelo Mai descubrió en la Biblioteca Vaticana un manuscrito completo. 
nar desaparecen sin tener ningún significado. ${ }^{65}$ Este tipo de visión es sin duda la que tiene Polifilo, quien anuncia que ha pasado una noche insomne antes de caer dormido. Según Macrobio la palabra insomnio no hace referencia sólo a aquello que se ve a través de los sueños, sino a lo que sólo en sueños es creíble, característica del hypnós.

Escipión experimenta un somnium, ya que lo que acontece se encuentra cubierto por una vela de sabiduría, es también un oraculum porque Paulo y el Africano le anuncian a Escipión que morirá asesinado, y es un visum porque contempla los mismos lugares donde estará después de su muerte, tal y como dice Macrobio. ${ }^{66}$ Así, en el Sueño de Escipión encontramos los tres principales tipos de sueños, por lo que también nos es lícito inscribir las visiones de Polifilo dentro de más de una categoría.

Polifilo dentro de su sueño cae dormido y entra en un segundo sueño. La primera parte de su visión se caracteriza por ser primordialmente angustiosa, ya que su protagonista está perdido en un bosque oscuro lleno de temor. Esta primera ensoñación es sin duda un fántasma o visum. Esta clase de sueños se distingue por ocurrir entre la vigilia y el profundo adormecimiento, es como una primera nube de sueño en el que diferentes formas van y vienen en diferente magnitud y especie, llenas de asuntos turbulentos o alegres. ${ }^{67} \mathrm{La}$ acción de dormir dentro del sueño señala el cambio de experiencia onírica que acontece a Polifilo.

En palabras de Polifilo, sin demora tras cerrar los párpados enrojecidos sobre sus ojos hinchados, "a través de la acerba vida y la suave muerte, fue invadida aquella parte ocupada y oprimida por un dulce sueńo, que con la mente y con los amantes y por el espíritu vigilante no está unida, ni participa de altas operaciones". ${ }^{68}$ Entonces, así como nos había anunciado que sufría por un no próspero amor, experimenta en su dormir una aventura con su muy querida Polia. Sin embargo su despertar, anunciado por el canto de Filomela, es la despedida de su amada ninfa: "Adiós pues Polia" ${ }^{69}$ La realidad no ha cambiado,

65. Macrobio, Commentaria, I.3.4-5.

66. Macrobio, Commentaria, I.3.I2-I3.

67. Macrobio, Commentaria, I.3.7.

68. "Hora li madidi ochii uno pocho tra le rubente palpebre rachiusi, sencia dimorare tra uita acerba, et suave morte. Fue inuasa et quella parte occupata et da uno dolce somno oppressa, la quale cum la mente et cum gli amanti et per uigili spiriti non sta unita ne participe ad si alte operatione". Francesco Colonna, The Dream of Poliphilus, Facsimiles of One Hundred and Sixty-eight Woodcuts in "Poliphili Hypnerotomachia" (Venecia: I499), sig. a iii.

69. "Vale ergo Polia", en Colonna, The Dream of Poliphilus, sig. f iii. 
Polia no despertará de la muerte, su sueño final. Por lo que la primera clasificación le queda bien a esta experiencia.

Sin embargo, Escipión y Polifilo también tienen algo en común y es que el hypnós de Polifilo tiene algo de somnium. Macrobio nos dice que normalmente los sueños de este tipo están velados por enigmas cuyo significado es incomprensible y sin interpretación, a cuya naturaleza no tenemos acceso. ${ }^{70}$ Así, Polifilo se encuentra a lo largo de su recorrido con adivinanzas que ni él puede resolver y escrituras cuyo lenguaje es incapaz de descifrar, característica de la tradición onírica en el Renacimiento. ${ }^{71}$ Además la serie de lugares que visita, de personajes que conoce e incluso los platillos que consume, son parte de una gran alegoría onírica.

Si los lectores de la Hypnerotomachia han encontrado su contenido demasiado pesado y la trama incoherente o sin sentido es porque no han pensado en sus propios sueños. Por ejemplo, Polifilo al encontrarse frente a la gran pirámide coronada por un obelisco, cuando inicia su recorrido, sabe a primera vista cuántos escalones la componen y las medidas exactas de su largo, ancho y altura. Esto no es sorprendente, también Escipión comprende la bóveda celeste entera en su ensońación, y no sólo él, todos en nuestros sueños somos poseedores del conocimiento absoluto de lo que ocurre. También se acusa a Polifilo de lo fragmentario de su narración, en particular de los saltos en tiempo y espacio que realiza. Así también Escipión asciende a la bóveda celeste y desciende de regreso a la tierra sin que comprendamos su movimiento, pero cuando reflexionamos sobre este aspecto, sabemos que es natural que las cosas se den de esta manera, diríamos "como entre sueños" 72

Finalmente, todo lo que observa nuestro héroe en su andar onírico resulta casi irreal, como el gigantesco elefante de piedra negra que es un edificio, el gran cuerpo humano dentro del cual se puede andar sin dificultad, el jardín de cristal o las tres puertas que conducen, una junto a la otra, a mundos distintos. Todo esto sin contar la serie de máquinas y artefactos que para su época eran de sueño, como las puertas que se abren solas, las fuentes andantes y los mosaicos fluorescentes, aunque hoy son cosa de todos los días. Pero el asunto que ocupa a este trabajo es cómo representar todo eso: lo irreal, lo imposible, lo que sólo vemos con los ojos cerrados.

70. Macrobio, Commentaria, I.3.9.

71. Battisti, L'antirinascimento, I I8-I I9.

72. Reading Dreams. The Interpretation of Dreams from Chaucer to Shakespeare, ed. Peter Brown (Nueva York: Oxford University Press, 1999). 
La mayor parte de la Hypnerotomachia la ocupan las minuciosas descripciones que realiza su protagonista, algunas de éstas podemos llamarlas ecfrásticas. El griego Hermógenes fue el primero en definir la écfrasis como el recuento energético y visible que hace evidente lo descrito. Las écfrasis pueden ser de personas, cosas, acciones, lugares y muchas otras cosas. ${ }^{73}$ Esta definición parte del análisis etimológico de la palabra compuesta por la preposición griega $e k$ : afuera y el verbo phrázo: narrar. El vocablo se refiere a narrar hacia afuera, traer ante los ojos de mis lectores/oyentes aquello que puedo ver dentro de mi cabeza. Ya desde la antigüedad los escritores entendían el paralelo entre el arte verbal y el visual. Ambos tienen la capacidad de contribuir a la verdad haciendo visible lo invisible, o sea, revelar el mundo interior de las emociones por medio de la pintura o la poesía. ${ }^{74}$ Esta distinción se vuelve indispensable cuando hablamos de Polifilo. Recordemos que él narra aquello que vivió en sueños y, por tanto, que sólo contempló en su imaginación. Se da a la tarea de extraer de sí mismo de manera detallada y a veces vívida lo que sólo fue una experiencia onírica, por tanto subjetiva, individual, única y efímera. Por esto pienso que si bien no todas las descripciones de Polifilo pueden ser llamadas ecfrásticas, su sueño en conjunto sin duda lo es.

Recordemos que la Hypnerotomachia es un libro ilustrado y esas xilografías que hoy resultan ingenuas o poco agraciadas cumplen esta difícil tarea: representar lo que se nos presenta irrepresentable a través de estas descripciones ecfrásticas. Si bien Polifilo ve edificios y esculturas entre las que los materiales más recurrentes son el mármol, el pórfido y otras piedras de diferentes colores, además de gemas preciosas, como el jaspe y la calcedonia, y metales como el oro, la plata y el cobre, lo que observamos en las xilografías no es más que tinta y papel en dos dimensiones. Por tanto no las podemos considerar la copia fiel de lo descrito ni mucho menos, sino simplemente la ilustración ${ }^{75}$ de lo que tal vez, sólo en palabras, no lograríamos representar mentalmente.

Murray Krieger ha diferenciado entre las características de la écfrasis la ambición. ${ }^{76}$ Esto quiere decir, la extraordinaria tarea que se da el poeta de repre-

73. Hermógenes, Progymnasmata, X; Stephen G. Nichols, "Seeing Food: An Anthropology of Ekphrasis, and Still Life in Classical and Medieval Examples”, $M L N$ Io6, núm. 4, French Issue: Culture Representations of Food (septiembre, I99I): 82I.

74. Nichols, "Seeing Food", 822, respecto del trabajo Imagines de Filóstrato, célebre escritor griego de écfrasis.

75. Del latín illustrare que quiere decir sacar a la luz, descubrir, aclarar un asunto, tal y como en el caso del libro de Polifilo.

76. Murray Krieger, "The Problem of Ekphrasis: Image and Words, Space and Time-and 
sentar lo irrepresentable. Aquellos que escriben sobre sueños se dan el lujo de construir con palabras palacios sin cimientos, como Polifilo, cuyas visiones son tan amplias en extensión como en lujo de ornamentos, de motivos y materiales. Pero lo que distingue a la Hypnerotomachia es que su creador ideó artefactos, esculturas, edificios y altos relieves que contienen historias que no necesitan de ningún tiempo ni ningún espacio adicional al del mundo onírico de Polifilo en el que su narración nos atrapa inevitablemente, como ocurre en todo hypnós. Las creaciones de la Hypnerotomachia invitan a sus lectores a hacer recorridos que parten desde profundas bases para levantarse hasta altas cumbres. Razón por la cual múltiples artistas han buscado traerlas a la realidad y muchos, hasta nuestros días, buscamos vivir en su mundo de sueño.

\section{El Ninfeo de los cinco sentidos}

Si bien los numerosos estudios sugieren que la presencia de la Hypnerotomachia en diferentes expresiones del arte resulta inabarcable, éste se centra únicamente en aquellos jardines del Renacimiento italiano que no pudieron desconocer su relevancia, y en particular el creado por Pier Francesco Orsini. En I552 Pier Francesco Orsini comenzó la construcción de un jardín lleno de maravillas. Dedicó su vida a su boschetto, como él lo llamaba, hasta 1584 cuando murió. La creación de este paisaje de sueños se vio interrumpida por la participación de Vicino, como llamaban carińosamente a Pier Francesco, en las múltiples batallas que se libraban en Italia en la época. Vicino fue un gran capitán en la guerra, sin embargo, la vida de alianzas políticas y militares regidas por diversos intereses, en particular el económico, ya que la familia Orsini era tradicionalmente de condottieri, terminó por hastiarlo. Por esta razón decidió aislarse en su jardín en Bomarzo. Vicino, desde su temprana juventud, demostró alta sensibilidad hacia las artes y las letras, y para alimentar su carácter melancólico, su vida se vio marcada por profundas pérdidas amorosas. Como buen hombre del Renacimiento, su formación como poeta y humanista no se vio anulada por su vida de soldado. Así los últimos años de su vida pudo dedicarlos a la reflexión en la tranquila vida de Bomarzo y sus Maravillas.77

the Literary Work", en Pictures into Words, ed. Valerie Robillard (Ámsterdam: vu University Press, 1998), 3-20, especialmente 4-ss.

77. Para más información sobre el Sacro Bosco el lector se puede remitir a mi trabajo "La 
La presencia de Polifilo en Bomarzo ha sido estudiada en más de un par de ocasiones, pero en este breve estudio, más allá de intentar abarcar el jardín entero, propongo la puntual y atenta lectura de un pequeño fragmento del conjunto escultórico. ${ }^{78}$

Polifilo en el libro VIII de su narración conoce a cinco ninfas llamadas Aphea, Osfressia, Orassia, Achoe y Geussia, en las que reconocemos a los cinco sentidos (fig. 9). La primera, Aphea, se distingue por acercarse y pedir a Polifilo que le dé la mano, su nombre se desprende del verbo griego apháo, que significa tocar. ${ }^{79}$ Se trata sin duda del sentido del tacto representado de la misma manera que Badius Ascensius seleccionó para su Stultifera Navis. ${ }^{80}$ Este libro francés de 1500 guarda varias semejanzas con el de Polifilo. Por ejemplo, Badius, quien basó su obra en la alemana Das Narren-Schiff, decidió deliberadamente cambiar la dirección de su embarcación. Los necios de la edición francesa y su traducción al latín se dirigen a la isla de Cythera, en lugar de la isla de los Necios, modificando la versión alemana y de manera semejante a Polifilo que se embarcará en la nave de Cupido a la isla de Venus. En la embarcación dedicada al tacto vemos a la personificación de este sentido de pie al medio mientras toma la mano de un necio y besa a otro (fig. Io). Se había considerado ésta como la primera aparición de tal atributo para el sentido del tacto, que a partir de este momento se volverá la más aceptada. Sin embargo, al compararla con la presencia en el Sueño de Polifilo tendremos que declarar un muy cerrado empate. Pero lo más sorprendente en la aparición de la ninfa Aphea está en su jerarquía. Debemos entender que la intención del autor al presentar en primer lugar el tacto es destacar la primacía que le otorga a éste entre los otros sentidos, completamente único y atípico. La tradición desde Aristóteles dio a la vista el primer lugar, ${ }^{8 \mathrm{I}}$ siempre perseguida de cerca por el oído, y aunque los estudiosos han peleado por el lugar entre estas dos, nunca nadie premió al tacto con tal honor. Dentro de la ensońación de Polifilo no resulta sorprendente esta

metamorfosi di Ovidio e il sogno di Polifilo nel giardino delle meraviglie di Pierfrancesco Orsini", antecedente inmediato de este ensayo, en el tomo Il Sacro Bosco a cargo de Sabine Frommel (Milán: Electa, 2009) I50-I55. En la bibliografía de este trabajo se detallan otras fuentes.

78. Tanto el señor Battisti, L'antirinascimento, I24-I37 como Kretzulesco-Quaranta, Los jardines del Sueño, 27I-286, procuraron en sus publicaciones dar un amplio vistazo al conjunto sin hablar con particular interés de ninguna escultura.

79. "Da mi la mano [...] Et io me chiamo Aphea". Éste como todos los textos referidos siguen la edición veneciana de I499, The Dream of Poliphilus, sig. e iiii-ss.

80. La nave de las Necias.

8I. Aristóteles, De anima, 4I8a.26. 


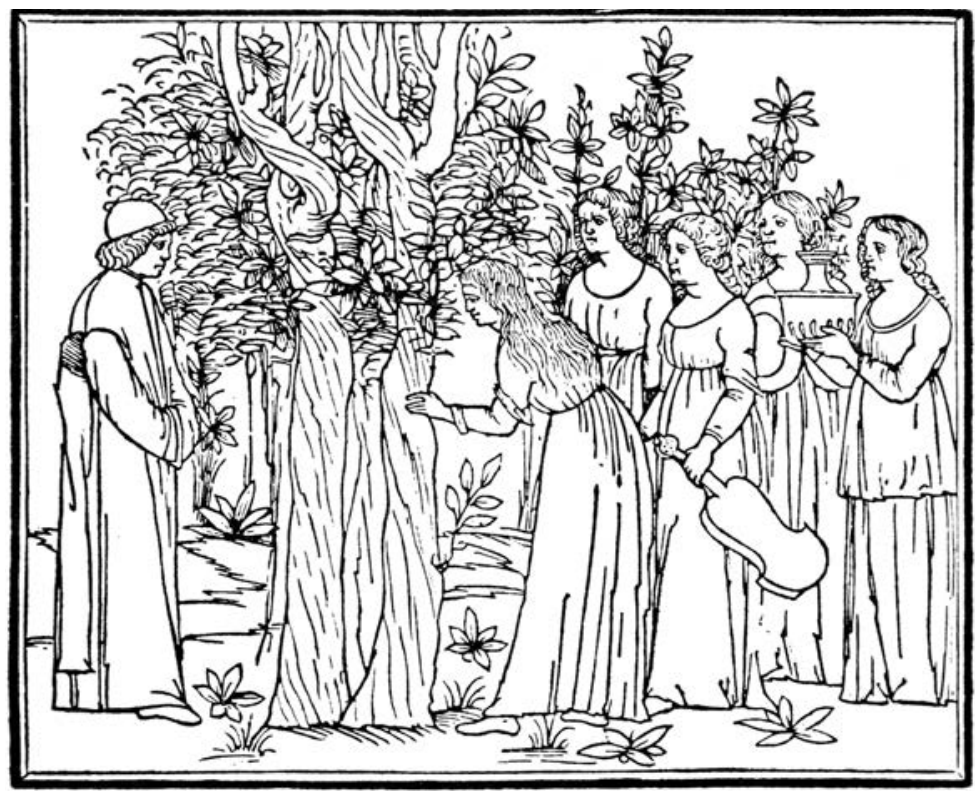

9. Polifilo y las cinco ninfas, Hypnerotomachia Poliphili, I 499, tomado de Francesco Colonna, Hypnerotomachia Poliphili. The Strife of Love in a Dream, trad. e introd. Joscelyn Godwin (Londres: Thames and Hudson, 1999), 76.

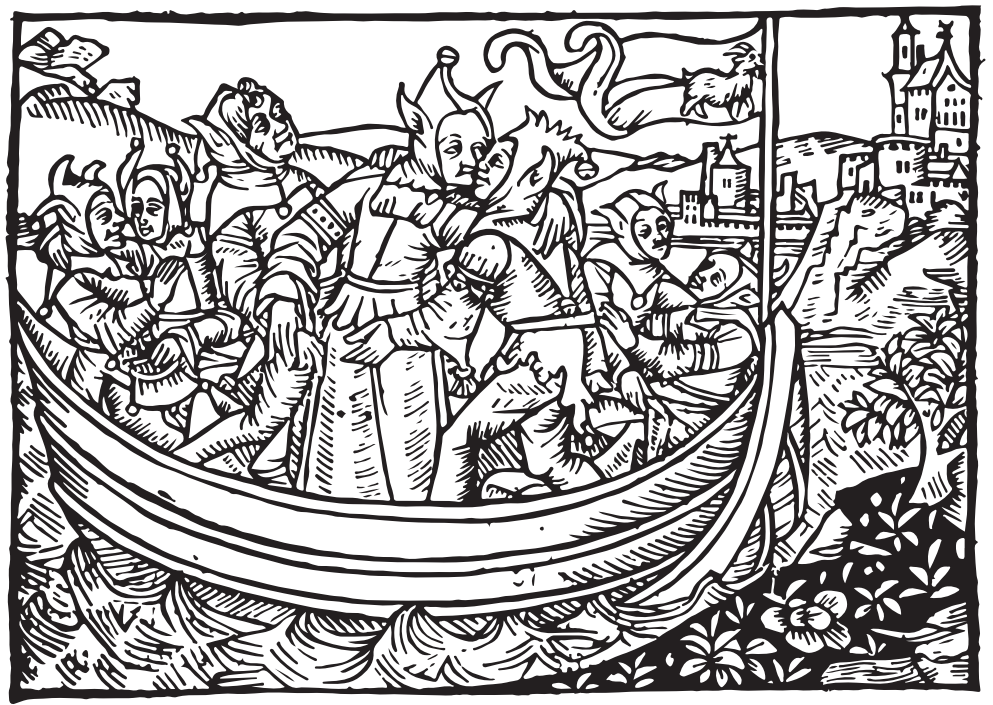

Io. Josse Bade, La nave del Tacto, Stultifera Navis, Burgos, I500. Biblioteca Histórica, Universidad Complutense de Madrid. 
selección, ya que como leeremos más adelante, la experiencia que le ofrecen las voluptuosas ninfas es principalmente táctil.

La segunda ninfa es Osfressia que lleva perfumeros y sábanas blanquísimas, ${ }^{82}$ entendemos limpias y perfumadas; es sin duda, como indica su nombre derivado del griego osphraínomai, el olfato. A ella le sigue Orassia, del verbo oráo, portadora de un brillante y espléndido espejo, ${ }^{83}$ es la vista. En cuarto lugar con una lira aparece la llamada Achoe, ${ }^{84}$ del griego akoúo, el oído, y finalmente, Geussia, derivado de geúo, que porta el vaso de un preciosísimo licor, ${ }^{85}$ es el gusto.

Entonces Polifilo, tras una amable invitación, acompaña a las bellas ninfas al baño al que se dirigían. Se muestra desde el comienzo sorprendido por la belleza del edificio octogonal al que lo conducen. Primero por el bello friso que lo envuelve y la hermosa cúpula de cobre que lo corona; al interior, por los ricos adornos del baño hechos de jaspe y calcedonia de todos los colores, piedra galactita ${ }^{86}$ y mosaicos de diversos tonos. Los muros están hechos de una lisa piedra de un fuerte color negro, y el techo decorado con cristales, piedras y oro. En este sitio sus acompañantes se desnudan sin pudor para bañarse y terminan por convencer al tímido Polifilo de que lo haga también. Éste se muestra excitado por la bella desnudez de sus acompañantes y los numerosos placeres a los que se ve expuesto. Un riquísimo aroma llena el espacio, el agua limpísima está tibia y resulta sumamente agradable, sin contar que todo lo que observa lo colma de goce. Al terminar el baño las amables ninfas regalan a Polifilo un nuevo traje y le obsequian un ungüento para revivir sus fuerzas. Aunque un poco apenado al principio, el héroe descubre su cuerpo contorsionándose en lascivo ardor a causa del regalo de las ninfas. Placer del que las ninfas formarán parte desviando su camino en un alegre juego. Una vez saciado, Polifilo toma una yerba medicinal, la amella, y tranquiliza su ánimo para continuar en compañía de las ninfas al palacio de su reina Eleutheryda.

Este pasaje de la aventura onírica de Polifilo resulta llamativo por su fuerte carga sensual, razón por la cual algunos han querido ver en el total de la ensoña-

82. "Et questa che porta li buxuli et gli bianchissimi linteamenti, e nominata Osfressia", Hypnerotomachia Poliphili (Venecia: I499), sig. e iiii.

83. "Et questa altra che dil splendente speculo (delitie nostre) e gerula, Orassia e il suo nome", Hypnerotomachhia Poliphili, sig. e iiii.

84. "Costei che tene la sonora lyra, e dicta Achoe", Hypnerotomachhia Poliphili, e iiii.

85. "Questa ultima, che questo vaso di pretiosissimo liquore baiula, ha nome Geussia", Hypnerotomachia Poliphili, sig. e iiii.

86. Denominada así por su color blanquísimo, Plinio XXXVII, I62. 


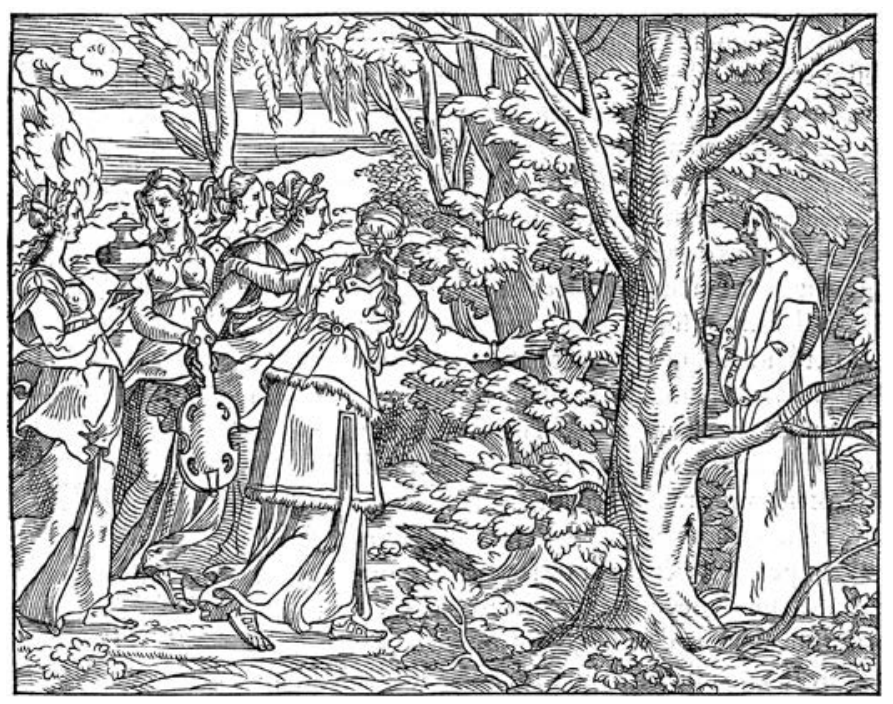

I I. Polifilo y las cinco ninfas, Le Songe de Poliphile, I546. Biblioteca Nacional de Francia.

ción de Polifilo una aventura erótica; ${ }^{87}$ afirmación difícil de sostener en una obra $\tan$ rica en tan diversos motivos. Lo que es cierto es que la fuerza de este encuentro no pasa desapercibida a los atentos lectores. Por ejemplo, podemos atribuir a ello que el ilustrador francés haya decidido añadir dos imágenes nuevas sólo a este pequeño pasaje (fig. II). Una de ellas muestra el edificio por fuera (fig. I2), y la otra a las bellas ninfas desnudas frente a Polifilo al interior de las termas (fig. I3). Asimismo, supongo que fue esta misma inquietud la que llevó a Pier Francesco Orsini a construir en su jardín un monumento a estas bellas ninfas.

Vemos en el Sacro Bosco de Bomarzo las ruinas de lo que debió ser una lujosa habitación (fig. I4). Con tres muros en lugar de ocho, en una pequeña oquedad formada en las terrazas naturales de la pendiente donde fue concebido el conjunto, notamos todavía los restos de una bóveda de cañón que debió cubrirla. Imaginamos la entrada velada por una elegante cortina y su interior recubierto por ricos tejidos, cojines y cobertores que debieron hacerlo bastante cómodo. Podemos sumar a la belleza de la decoración, un rico perfume que impregnara el ambiente y otras delicias como alimento y bebida. Esta

87. Alberto Pérez-Gómez, Polyphilo or the Dark Forest Revisted. An Erotic Epiphany of Architecture (Cambridge y Londres: Mit Press, 1994). 
DOI: http://dx.doi.org/10.22201/iie.18703062e.2014.104.2513
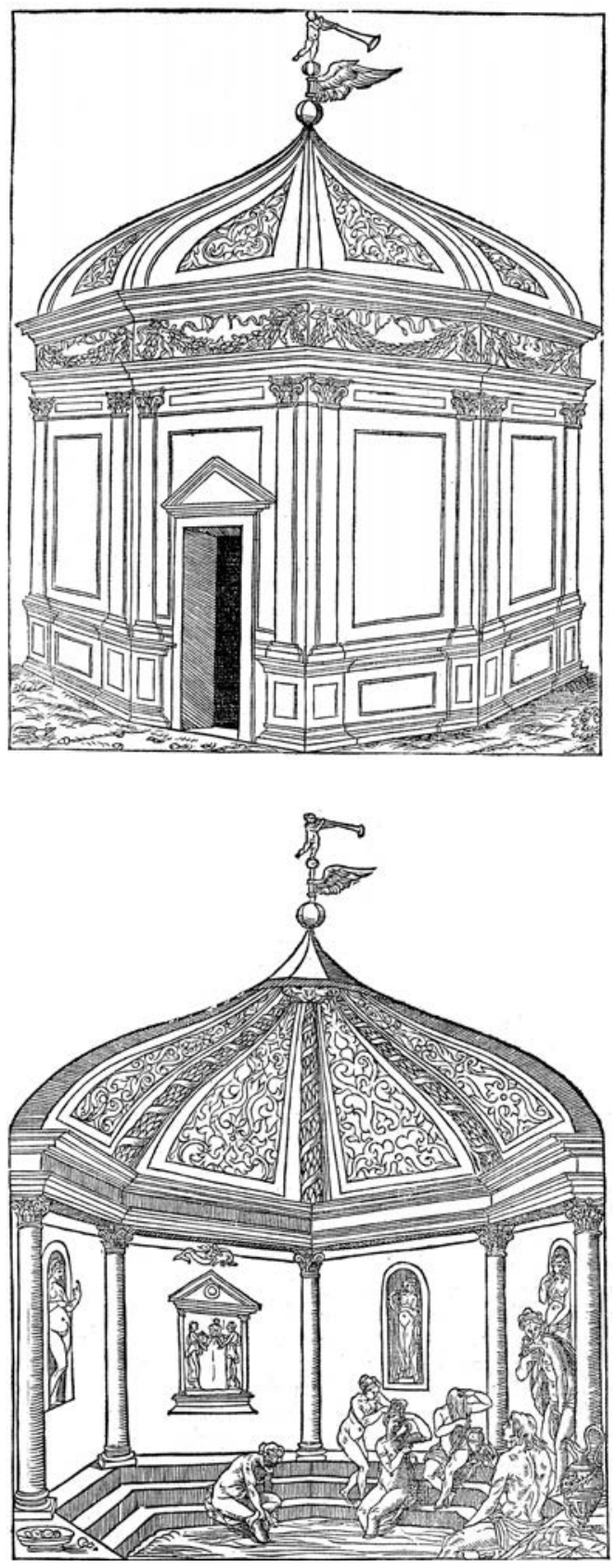

I2. Vista exterior del baño, $L e$

Songe de Poliphile, 1546. Biblioteca Nacional de Francia.
I3. El baño de las ninfas, Le Songe de Poliphile, I546. Biblioteca Nacional de Francia. 


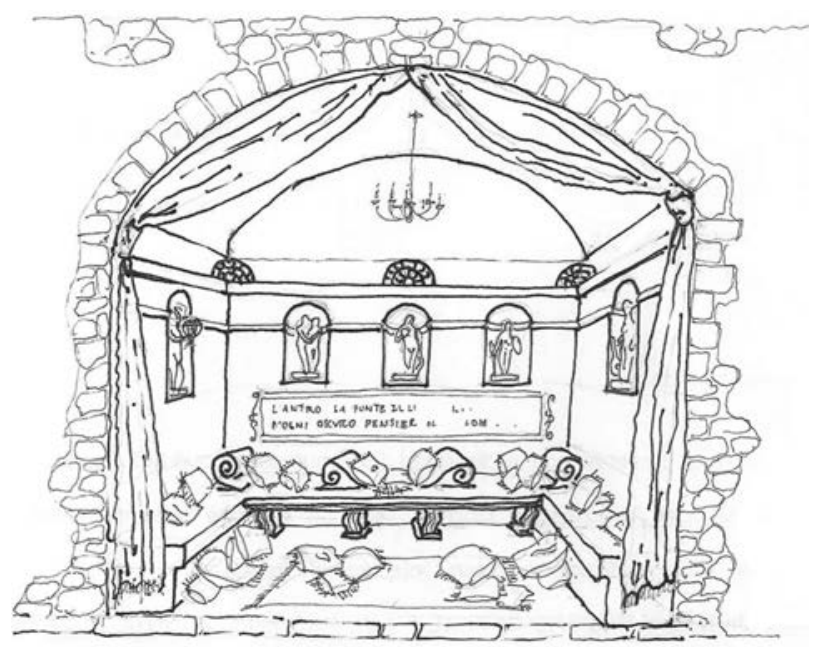

I4. Recreación del Ninfeo de Bomarzo, dibujo de José G. Amozurrutia.

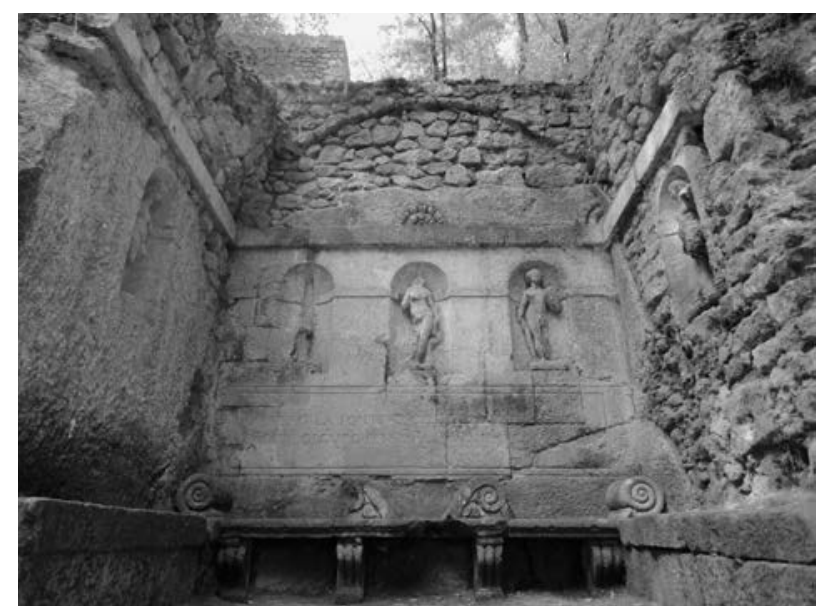

I5. El Ninfeo de Bomarzo de I552, hoy. Foto: Sandra Álvarez Hernández. 
recreación parte de las esculturas que ocupan sus muros, o las pocas que quedan, y los restos de una inscripción apenas legible (fig. I5).

Cinco nichos distribuidos, tres en el muro principal y uno en cada muro lateral, se encontraban ocupados por las figuras de cinco ninfas, hoy sólo cuatro. Mal conservadas a causa de la intemperie y la destrucción que sufrió el lugar, apenas distinguimos que sostienen diferentes objetos. Sería imposible buscar adivinar los atributos de cada una, pero podemos aventurarnos a pensar que eran portadoras de un espejo, un frasco con perfume y unas sábanas, una lira, un vaso y, acaso, aquella faltante gozara de un compañero, razón por la cual algún pudoroso conservador decidió destruirla. La silueta de los nichos coincide con la descrita en los baños de la Hypnerotomachia, e incluso la posición de las ninfas resulta sumamente similar a aquella de las diseñadas por el ilustrador francés.

Finalmente la idea se ve redondeada por las escasas palabras conservadas en el muro:

La cueva, la fuente, el bel [...] y la sombra de todo oscuro pensamiento ensombrece el alma. ${ }^{88}$

Éstas hacen eco del pasaje de la narración de Polifilo donde, después de contemplar las bellas fuentes que alimentan las termas, se ve invadido por oscuros y lascivos pensamientos. Por ejemplo, el héroe suplica a las ninfas: "Oh, mujeres de fuego y de mis maldiciones, ¿qué me han hecho? Me dan lícita ocasión de irrumpir y oprimir y de violentarlas." 89

Las termas octogonales en las que se baña Polifilo acompañado de cinco lascivas ninfas son parte de un sueño. El pequeño Ninfeo construido en Bomarzo es la realización de algo que sólo puede existir en la fantasía, es la creación de una mente ingeniosa y erudita, la de un soñador como Pier Franceso Orsini. Sin duda el Sacro Bosco de Bomarzo es un lugar de sueńos, se puede notar en su recorrido lleno de giros y figuras sorprendentes fuera de proporción, por ejemplo el conjunto de una enorme tortuga sobre la que camina una bella ninfa en dirección a las fauces de una ballena, al lado de un pequeño monte Helicón

88. "L'antro la fonte il bel [...] et l'ombra d'ogni oscvro / pensier gli animi sgombra", restos de una inscripción en el Ninfeo de Bomarzo.

89. "O foemine ignibonde et di me mallefice, cusi mi fate uui? Ecco che modo licita occasione di irrumpere et opprimere et di uui fare uiolentia excusabile mi se praesta", Hypnerotomachia (Venecia, I499), sig. e viii. 
I6. Ilustración de la Hypnerotomachia

Poliphili, I499. Biblioteca Nacional de Francia.

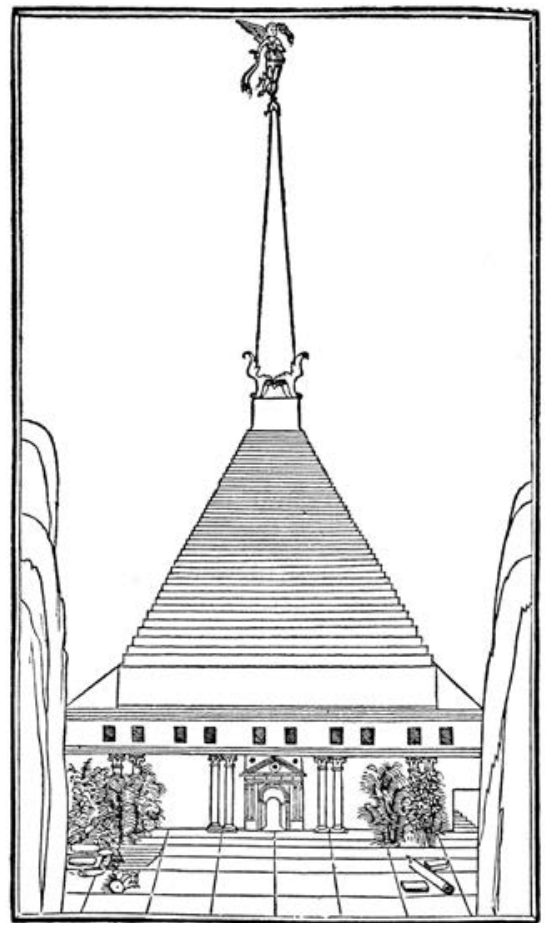

coronado por un pegaso. Este conjunto es comparable con aquel que ve Polifilo conformado por una gran pirámide, un caballo alado y un enorme coloso por cuya boca puede entrar (fig. I6). Los dos modifican la escala de lo real, en Bomarzo con una tortuga gigante, y en la Hypnerotomachia con un enorme cuerpo humano. En los dos aparece una ninfa caminando sobre una esfera, en la punta del obelisco que corona la pirámide que ve Polifilo, y sobre la tortuga de Bomarzo. En los dos también hay un caballo alado y unas enormes fauces que invitan a acercarse, y también en ambos casos el conjunto está claramente formado por tres piezas, que en el relato de Polifilo se unen al interior del mismo libro y en Bomarzo se distribuyen en una misma plaza.

Finalmente, el encanto de la ensońación bomarciana se resume en pocas palabras:

Sólo por desfogar el corazón. ${ }^{90}$

90. "Sol per sfogar il core". Inscripción en una columna del Bosco de Bomarzo, junto a ella 
Así también, el hypnós de Polifilo es la única salida a su profunda cuita amorosa. Pier Francesco Orsini, como los sabios humanistas de la época que se deben haber identificado con nuestro héroe Polifilo, eran peregrinos. Su viaje y su búsqueda se encontraban en los libros y en la sabiduría antigua. Su nave, al estilo de la de las Necias, debía surcar aguas peligrosas en la búsqueda de Polia, a veces sin mapa ni brújula. El encuentro con sus cinco sentidos, el volverse dueños de su percepción, era sólo una parada en su incansable camino. ${ }^{91}$

\section{La búsqueda del peregrino}

El Sueño de Polifilo, como hemos visto, es una búsqueda en realidad. La búsqueda de un remedio al mal de amores que sufre nuestro héroe, y el medio para encontrarlo es el sueńo. A la tarea de encontrar un remedio en la observación de los síntomas de una enfermedad los médicos le llaman diagnosticar, ${ }^{92}$ y es exactamente lo que nuestro héroe hace en su sueño. El peregrinar de Polifilo, cuyo fin procuraremos establecer en el conocimiento, puede definirse en la atenta lectura de este verbo.

La palabra diagnóstico se conforma por la preposición griega día, que significa "a través de" y gnosis, "conocimiento". Desde sus orígenes, juntos significan "medio para discernir", pero, si ponemos mayor atención, separados dicen más. La gnosis desempeñaba un papel de suma importancia en la filosofía grie-

se lee: "Vicinus Orsini I552", el sobrenombre cariñoso de Pier Francesco y el año de creación de su jardín.

9I. El tema del viaje o la búsqueda que realizaban los humanistas del Renacimiento es demasiado amplio para desarrollarse con detalle aquí. Una pequeña prueba de que el encuentro con los sentidos tenía un papel importante puede demostrarse, sin alejarnos de las fuentes ya citadas, en la exposición que hace Macrobio en sus Commentaria sobre el camino de descenso que realizan las almas por las esferas celestes al nacer, mismo que equivale a la famosa máxima socrática "Conócete a ti mismo" y que para él era un ejercicio de conocimiento personal. Véase Commentaria I.9., et infra, III. La búsqueda del peregrino. En la cuarta esfera, aquella gobernada por el sol, el alma adquiere su capacidad aisthetikón o sea, aquella que le da la facultad de percibir por medio de sus cinco sentidos, Commentaria i.I 2. Una bella comparación entre la alegoría polifilesca y este viaje astral es aquella desarrollada por Mino Gabriele, titulada Il Viaggio dell'Anima, publicada en su edición de la Hypnerotomachia Poliphili (Milán: Adelphi, 1998), XI-XXX.

92. Definición médica según el Diccionario de la Real Academia Española, vigésima segunda edición en línea http://buscon.rae.es/draeI/SrvltConsulta?TIPO_BUS=3\&LEMA=diagnostico 
ga, para Sócrates era el objetivo de la vida de todo filósofo ${ }^{93}$ y el verbo del que se desprende se leía en la famosa máxima "Conócete a ti mismo".94

Fue hasta los primeros años de nuestra era cuando surgió el gnosticismo, que es "un movimiento anterior al cristianismo y cuenta con sus propios orígenes". ${ }^{5}$ Se le llamó gnósticos a un conjunto de gentes, de ideas y de textos que creían poseer el conocimiento. Creían que por medio de la gnosis alcanzarían la salvación, con ayuda de un mesías, pero no el mesías cristiano, y no bajo los mismos términos. El hermetismo fue una de estas líneas religiosas, que nació antes que el cristianismo, alimentada de la religión griega antigua, el estoicismo y algunas influencias hebraicas, ${ }^{96}$ y que en el siglo xv volvió gracias al fuerte brote neoplatónico de la época. Existe una gran variedad de textos que se han titulado bajo el adjetivo de herméticos, hay los filosóficos o los religiosos, y los escritos relativos a magia, astrología y alquimia. ${ }^{97}$ Ambos son muy diferentes entre sí, y los que aquí nos ocupan son los filosóficos.

¿Por qué se les llama herméticos? Porque están elaborados a manera de un diálogo, como los que escribió Platón con la voz de su maestro Sócrates, en los que el que recibe las enseñanzas es alguien llamado Hermes. Hermes es el paralelo griego que encontraban los helenistas para el dios egipcio Thoth, el padre de la escritura. Y también,

Hermes fue un hombre como tú y como yo —un hombre que vivió en Egipto hace mucho tiempo, en tiempos del rey Amón. Pero fue un hombre que alcanzó la gnosis (esto es el conocimiento de Dios, pero un tipo de "conocimiento" que involucra la unión con Dios); y fue el primero y más grande instructor de la gnosis. Falleció, como fallecen los demás hombres; y tras su muerte devino dios —igual que tú y yo también, si alcanzamos la gnosis, devendremos dioses tras la muerte..$^{98}$

Se dice que a Thoth ya se le daba el epíteto del "tres veces grande", ${ }^{99}$ pero tal vez el Hermes Trimegisto, ${ }^{100}$ supuesto autor de estos textos, gozaba de este epí-

93. Afirmación largamente desarrollada en el Fedón de Platón, i I 4 C-ss., y otros diálogos.

94. Gnothi seauton.

95. Wilhem Bousset, en Roberto Sánchez Valencia, De la heterodoxia a la ortodoxia (México: Universidad Iberoamericana, 2007), 59.

96. Frances Yates, Giordano Bruno y la tradición hermética (Barcelona: Ariel, 1983), I9.

97. Walter Scott, Corpus hermeticum y otros textos apócrifos (Madrid: EDAF, 2006), 9.

98. Scott, Corpus hermeticum, I5-I6.

99. Frances Yates, Giordano Bruno y la tradición hermética, I8.

ıoo. Del griego tria y megistós, literalmente "tres veces el mayor". 
teto por las tres identidades que tenía y acabamos de enumerar: Thoth, Hermes y un hombre, como tú y como yo; también, triple naturaleza a la que debía su inmensa sabiduría. ${ }^{10 I}$ Entre los textos más importantes atribuidos a él, conservados hasta nuestros días, se encuentran el Pimander y el Asclepius.

Frances Yates en su estudio titulado Giordano Bruno y la tradición hermética afirma que sólo "con un cierto grado de simpatía en la enorme ilusión de su lejana antigüedad y de su carácter egipcio puede esperarse llegar a captar plenamente la enorme influencia"102 que el Corpus hermeticum alcanzó sobre sus lectores durante el Renacimiento. Al seguir esta postura, le atribuiré también la autoría del texto a Hermes, el antiguo dios griego, el tres veces grande, y fechando su origen en la más remota antigüedad. ${ }^{\text {I03 }}$

\section{Polifilo, hermético por excelencia}

Durante el Renacimiento textos de sabiduría antiquísima cobraron relevancia en los grandes movimientos progresistas de la época, como fue el caso del Pimander y el Asclepius. En I460 llegaron a Florencia una serie de manuscritos griegos en manos de los doctores bizantinos, como Gemisto Pletón, que asistían al Concilio festejado en esa ciudad. Entre estos documentos se encontraba una versión incompleta del Pimander, ${ }^{104} \mathrm{y}$ por orden de Cosme de Medici, Marsilio Ficino ${ }^{\mathrm{IO}}$ se dio a la tarea de traducirlos inmediatamente, posponiendo

ıог. El prefijo griego tris- puede utilizarse sólo para intensificar el significado de un adjetivo, pero, al ser megistós, por sí solo el superlativo de mégas la intención resultaría extraña, además al leer las enseñanzas de Hermes aprendemos sobre sus tres principios: el teológico, el cosmológico y el antropológico, que marcan también la línea de sus disertaciones. En fin, entendemos la importancia de sus tres potestades, sus tres cabezas o sus tres principales ideas.

I02. Yates, Giordano Bruno, 38.

I03. A pesar de saber que se trata de una compilación de textos que no pueden datar más allá del primer siglo de nuestra época y cuyo autor se conoce por nombre y apellido.

I04. Faltaba el último diálogo, el xv.

I05. A Marsilio Ficino (I433-I 499) le debemos el fuerte brote neoplátonico ocurrido en Florencia en el siglo Xv tras la fundación de su Academia Platónica Florentina. Tradujo principalmente a Platón y a Plotino. La traducción de los libros I-XIV del Corpus hermeticum contenidos en el manuscrito que recibió, y que incluía entre otras obras la Dialéctica de Boecio, estuvo lista en I 47I. Este mismo manuscrito es el que después pertenecería a Angelo Poliziano, como señala una nota. 
así su trabajo en la obra platónica. ${ }^{106}$ Esta nueva traducción de los textos del tres veces grande dio inicio a una larga tradición hermética. Los humanistas que se acercaban a estos textos lo hacían convencidos de que se trataba de textos escritos por la mano de Hermes en épocas remotas; y además, resultaban un medio útil para conciliar el viejo paganismo con el cristianismo, a causa de su contenido sincrético. Su importancia fue tal que inspiraron nuevas formas de pensamiento y modos de explicar la vida, el mundo y el cosmos entero.

Uno de esos textos, inspirados en la absoluta creencia en un verdadero Hermes, fue la Hypnerotomachia Poliphili. Al Sueño de Polifilo de I499 se le ha llamado "el más bello libro del Renacimiento" ${ }^{\circ 07}$ y el primer calificativo que suele aparecer en la enumeración de sus cualidades es el de "hermético". Lamentablemente hoy día el adjetivo inspirado en el nombre del dios griego suele tener varios calificativos, antes que su conexión con el antiguo gnosticismo de los albores de nuestra era. Pero el libro de Polifilo ha sido apodado de este modo por diversas razones. Para empezar, el hermetismo de Polifilo no es el mismo que el del Corpus hermeticum. Los textos de los siglos xv y xvi que llevan este nombre estaban obligados, a causa de su contenido pagano, a guardar su más profunda identidad bajo un intrincado lenguaje alegórico y simbólico. De esta manera debemos entender que todo lo que se dice en ellos quiere decir otra cosa, oculta alguna profunda revelación que debía ser guardada de la mirada inquisitoria de la Iglesia católica. Así surgió la acepción que conocemos hoy día de "impenetrable", y la más vulgar, "que no deja entrar y salir el aire", ${ }^{108}$ ya que los escritos herméticos del Renacimiento guardaban tan bien sus secretos que hacía falta una enorme sabiduría para quebrar su elaborado código protector. ${ }^{\mathrm{I09}}$

La Hypnerotomachia está escrita en un lenguaje cifrado, parte toscano, parte latín y parte griego, mismo que observamos desde su título. Además, dentro de los paisajes que observa Polifilo a lo largo de su sueño, que ocupan los prime-

I06. Yates, Giordano Bruno y la tradición hermética, 30.

I07. Kretzulesco-Quaranta, Los jardines del Sueño, 7 I-ss.

I08. Diccionario de la Real Academia Española, vigésima segunda edición en línea. http:// buscon.rae.es/draeI/SrvltConsulta?TIPO_BUS=3\&LEMA=hermetico

ı09. Como establecía la criptografía de la época. El término criptografía refiere a "lenguajes, sobre todo en el ámbito escrito, para comunicar información de una manera velada, oculta — de ahí el término kryptos- a un destinatario sin que los demás tengan una percepción del mismo". Si bien el término se acuñó en el siglo xviII, la criptografía se practicó desde el antiguo Egipto. Véase "La criptografía en el mundo antiguo", Roberto Sánchez Valencia, Revista Digital Universitaria 7, núm. 7 (Io de julio de 2006), en línea: http://www.revista. unam.mx/vol.7/num7/art54/int54.html 
ros 24 de los 37 libros que lo componen, se encuentran jeroglíficos, emblemas, inscripciones en griego, latín, árabe y hebreo. Pero sobre todo, debemos comprender que todo lo que ve, piensa y dice Polifilo es sólo una metáfora dentro de la gran alegoría hermética.

El Sueño de amor y lucha de Polifilo trata de un amante que sufre de un "desgraciado amor" como ya vimos. Al inicio de la narración Polifilo cae dormido iniciando un viaje que sólo termina con su despertar para recordar que su amada Polia está muerta y despedirse de ella. ${ }^{\text {IIo }}$ Empero, si ya hemos afirmado que debemos entender todo lo que se dice aquí como el abrigo de algo más, sería ingenuo creer que la historia de Polifilo y Polia es sólo una historia de amor. Si bien los últimos trece libros, donde en voz de Polia leemos la anécdota de cómo nació el amor entre ellos dos, y de esta narración podemos desprender diferentes datos "históricos", como ha hecho Emanuela Kretzulesco-Quaranta, ${ }^{\text {III }}$ dando así a Polifilo la identidad de Lorenzo de Medici y a Polia la de Lucrezia Donati, lo cierto es que resulta más sabio buscar por debajo de las apariencias la identificación de los amantes. Así como diversos estudiosos han dado en afirmar que la Divina comedia no trata de Dante en busca de su amada Beatriz, sino que, bajo esta pantalla, debemos entender al hombre en su camino a la teología, debemos buscar al verdadero Polifilo en una peregrinación de mayores alcances. Tendríamos que sumar también a esto el hecho de que así como a Polifilo le será develada en su sueño una serie de principios, también a Hermes se le anunció la verdad mientras dormía. ${ }^{\text {II2 }}$

A fin de seguir los pasos de nuestro enamorado, comenzaremos por intentar develar la verdadera causa de su aflicción, y así, tal vez, este diagnóstico nos ayude a encontrar el conocimiento, objetivo final de su búsqueda.

I Io. La relación entre la muerte y el sueño goza de una amplia tradición. De hecho el Sueño de Escipión está inspirado en el capítulo relativo al mito de Er narrado al final de la Republica de Platón (6I 4b-62 Id) y la gran diferencia que guarda con éste es que Er en lugar de dormir, muere. Er, el hijo de Armenio, al doceavo día de ser velado despierta y cuenta todo lo que observó en el Hades. Así también el mito de Endimión a quien Zeus, por petición de su amada Selene, da vida eterna durmiendo, por lo que no despertará nunca de su sueño. En la literatura renacentista también podríamos recordar los versos de Shakespeare: "to die, to sleep,_ [...] to sleep, perchance to dream, ay there's the rub,/ for in that sleep of death what dreams may come...", Hamlet, III.I.6o-66.

I I I. Kretzulesco-Quaranta, Los jardines del Sueño, 33.

I I2. Véase Corpus hermeticum, I. 


\section{El coloso yacente}

Muy pronto dentro de su sueño, después de contemplar un par de paisajes ruinosos, Polifilo se encuentra con una obra de magnífica factura y naturaleza. Un extraño gemido lo invita a acercarse. Entonces ve un vastísimo y admirable coloso, con los pies ahuecados sin suela y todas las tibias horadadas y huecas. Después, aproximándose con horror a causa del sonido que surgía de él, llega a la cabeza y deduce que el aire que entraba por las plantas vacías causaba el gemido que se escuchaba. ${ }^{\text {II3 }}$ Este coloso yacente elaborado de metal, cuya apariencia es la de un hombre de edad mediana y que reposa su cabeza sobre un almohadón, tiene semblante de estar enfermo, su boca está elaborada de manera que pareciera suspirar y quejarse. Polifilo calcula que debe medir sesenta pies. Sube por los cabellos acomodados sobre el pecho, después por los abundantes y despeinados vellos de la resistente barba, hasta la boca abierta en un lamento. Dentro descubre que está todo laboriosamente tallado y hueco, entonces por curiosidad en un impulso baja por los escalones formados en la garganta y de ahí al estómago. Continúa asombrado por oscuros ductos hasta todas las partes de las vísceras internas. Observa todas las partes de un cuerpo humano, cada una con su nombre inscrito en tres idiomas, caldeo, griego y latín: intestinos, nervios, huesos, venas, músculos, carne; qué enfermedad se genera en ellos, la causa, la cura y el remedio. Para cada una de las vísceras aglomeradas había una puertita y cómodo acceso, y gracias a respiraderos distribuidos diversamente, se encontraban todos los lugares oportunamente iluminados.

En la narración Polifilo menciona que dentro de este asombroso coloso no se encuentra ni un órgano menos que en un cuerpo natural, pero sólo pausa su camino en uno: el corazón. Entonces lee cómo de amor se generan los suspiros y dónde el amor daña gravemente. Ahí, conmovido, desde lo profundo de su corazón emite un fuerte suspiro invocando a Polia. Lo horroriza en respuesta su sollozo amplificado por el arte de la estructura de metal de este enorme enfermo. ${ }^{\text {II } 4}$

Hemos repetido en un par de ocasiones que la Hypnerotomachia está acompañada de I7I xilografías, lo que quiere decir que podríamos creer que prác-

I13. "Echo ch' io vedo uno Vastissimo et mirando colosso, cum li pedi senza solea excavati et tutte le Tibie pervie et vacue. Et d'indi al capo cum horrore inspectabondo venendo, coniecturai che l'aura intromessa per le patorate piante, cum divino invento, il gemito moderatamente expresso causava...", Colonna, Hypnerotomachia Poliphili, sig. b vii.

I 4. El texto aquí citado es una versión elaborada a partir de mi traducción del lenguaje original. 
ticamente todo lo que en ella se ve tiene un apoyo gráfico para que el lector profundice en el conocimiento de lo que se le está develando. Pero cuando leemos atentamente el texto descubrimos que no es así, y entre las descripciones que carecen de ilustración encontramos ésta. ¿A qué se debe? Probablemente la realización de este diseño resultaba demasiado complicada al formar parte de una gran fantasía, pero quizá no. Quizá se tuvieron que recortar el número de ilustraciones a causa de la extensión y el coste del libro; o al ilustrador no le resultó lo bastante interesante este pasaje, cuya brevedad puede influir en esta apreciación. En este estudio, en el que deseamos acercarnos a los más profundos secretos de Polifilo, ninguna de estas respuestas es suficiente. Además, si ahondamos nuestra investigación, resulta que ninguna de las ediciones de Polifilo hasta la fecha ha ilustrado este pasaje.

Tampoco se proporcionan muchos datos para acercarnos a las fuentes de esta anatomía, pero sabemos que la selección del único órgano del cuerpo humano cuya descripción nos lee Polifilo no es casual: la información de su propio mal. En el corazón se dice "cómo se generan los suspiros del amor y dónde dańa el amor gravemente”. Pero la pregunta es: ¿por qué Polifilo ubica esta capacidad en este órgano?

Uno de los textos más leídos a lo largo de la historia para entender la creación del hombre fue el Timeo de Platón. De hecho en la época de Polifilo el traductor del Pimander, Marsilio Ficino, fue también el traductor de los diálogos socráticos. Por medio de la traducción de Ficino al latín, que permitió a los hombres de su época conocer la teoría platónica, sabemos que una vez que los dioses habían formado la cabeza, donde pusieron al alma inmortal, separaron al alma mortal y la colocaron en el tronco y las extremidades. En la parte superior, la más cercana a la cabeza, implantaron la parte belicosa del alma que participa de la valentía y el coraje para que pudiera escuchar a la razón. ${ }^{115}$ Después hicieron el corazón, nudo de las venas y fuente de la circulación de la sangre que se distribuye impetuosamente por todos los miembros. ${ }^{116}$ Este órgano era muy importante. Ficino para describirlo utiliza la frase regio stipatorum, que en español traducimos como la región de los guardias, haciendo referencia al término dorýforo, utilizado por Platón, y que en griego quiere decir literalmente

I I5. "Partem igitur animae fortitudinis iracundiaeque [...]ut haec obediens rationi,..." en la traducción del griego al latín elaborada por Marsilio Ficino publicada en I 542 en Basilea, 727.

I 16. "Cor vero venarum originem fontemque sanguinis per omne corpus quodam manantis", trad. Ficino, 727. 
que porta una lanza. También significa que se encuentra en la periferia y da nota de lo que acontece alrededor, como un satélite. Hoy día lo entenderíamos como un guardia fronterizo que se hace cargo de todo lo que llega a la puerta, sea bueno o sea malo. Por esta razón el corazón se encontraba expuesto a una situación peligrosa, por lo que a continuación se afirma:

Como ciertamente [los dioses] sabían que el corazón está expuesto a terribles sobresaltos, y es frecuente presa de la ira, y todo esto por obra del fuego, lo hicieron de la siguiente manera para temperar el calor. Los pulmones, cubierta del corazón, adhirieron, suaves y sin sangre primero, después como una esponja con huecos separado, para que con la respiración y la bebida entibien el ardor del corazón con alivio y consuelo. Por esta causa, desviaron las arterias como acueductos de la sustancia por los pulmones, para que así envolvieran con suavidad al mismo corazón en sus saltos. Para que cuando hierva excesiva la ira, de ahí la lleve más fácilmente hacia la obediencia, y apaciguado el tumulto ayude más propiciamente y pueda obrar con la razón. ${ }^{177}$

Donde leemos ira en ambas traducciones, el original griego de Platón utiliza la palabra thymós, para describir lo que siente el corazón. Esta palabra griega puede significar: ánimo, aliento, deseo, impulso, cólera, ira, gozo, amor, entre otras acepciones. Pero también puede referirse al mismo corazón, "lugar del enojo”, como asiento del pensamiento, la reflexión y la deliberación, por lo que podemos pensar que cuando Platón usa esta palabra se refiere a una serie de emociones y sentimientos que podríamos clasificar como "pasiones". ${ }^{\text {I18 }} \mathrm{Gra}$ -

I 17. "Cum vero cognoscerent cor rerum terribilium obiectu trepidaturum, \& ira saepius flagraturum, idque opus omne per ignem fore, aestus huiusmodi temperandi gratia, pulmonum tegmen cordi adhibuerunt, molle primum atque exangue, deinde cauis intrinsecus sistulis spongiae instar distinctum, ut spiritu potuque hausto cordis ardorem huiusmodi respiratione $\&$ refrigerio tepefaciat. Quam ob causam arterias tanquam aquaeductus per pulmonum substantiam deriuarunt, eamque cordi, quasi mollem saltum circundedere: ut quando nimia feruet ira, inde ad faciliorem obedientiam temperatum deferueat, sedatoque tumultu rationi facilius cum ira ministrare \& obsequi ualeat." Platón, Timeo, 70.a.7- 70.d.6. Aquí se cita la traducción del griego al latín que realizó Ficino, y que fue el medio por el cual los hombres de su época pudieron conocer a Platón. Ahí radica la importancia de leer esta versión del conocimiento platónico y no el original griego.

I 18. También puede hacer referencia al mismo corazón, razón por la cual Ficino decidió traducirla unas veces por animus, otras por ira, como es el caso, ya que ayuda a un mejor entendimiento del pasaje. Para comprender mejor esta distinción también podemos citar la definición según Macrobio de la capacidad del alma llamada thymikón, de la misma raíz, 
cias a esta información podemos deducir por qué Polifilo sitúa el origen de los suspiros en el corazón y las heridas del amor en él. Pero el por qué de su sufrir todavía sigue siendo un misterio, si seguimos creyendo que su amor por Polia no es lo que parece. La admiración que concluye la descripción del coloso nos da una clave para encontrar la fuente de su desazón:

$¡ \mathrm{Oh}$, preclaros ingenios pasados, oh edad verdaderamente áurea, cuando la virtud estaba de acuerdo con la fortuna, para este siglo dejaste como herencia la ignorancia y su igual, la avaricia! ${ }^{19}$

Esa edad de la que se habla aquí no puede ser otra más que la de Hermes, y eso lo sabemos al leer con atención el Asclepius. ${ }^{\mathrm{I} 20}$ En este diálogo se describe la religión egipcia junto a ritos y fórmulas mágicas. Ya avanzado el discurso, se nos anuncia que la religión de Egipto está destinada a desaparecer. Este siguiente apartado se conoce bajo el subtítulo de "El lamento" o "El apocalipsis", y cito un fragmento:

Oh Egipto, Egipto, tan sólo quedarán fábulas de tu religión y tus hijos, con el paso del tiempo, olvidarán tus creencias. Nada sobrevivirá para guardar memoria de tus piadosas obras, salvo las palabras esculpidas en la piedra y el Egipto inhabitado.

Entonces [...] ¿ Por qué llorar, oh Asclepio? ${ }^{121}$

¿No es acaso este mismo llanto el de Polifilo? Para el siglo xv la religión de Egipto había sido olvidada, el brazo de la Iglesia romana se extendía por amplios territorios, y en los siglos por venir su fuerza sólo se incrementaría, castigando otras creencias y formas de expresión.

thymós, la regida por Marte y que se ocupa de “animositatis ardorem”, los ardores del ánimo. Commentaria, I.I2.I3.

I19. "O aurea ueramente aetate, quando la uirtute concertaua et cum la fortuna. Solum ad questo saeculo relicta haereditaria la ignorantia et auaritia aemula lassasti”. Como aparece en el original de 1499 de Francesco Colonna, sig. b vii, reverso.

I20. Ficino no se dio a la tarea de traducir también este libro que ya era conocido. Su tradición fue muy amplia a lo largo de toda la Edad Media, igual que el libro III del Corpus hermeticum, Festugière, La Revelation d'Hermes Trimégiste (París: Les Belles Lettres, 1989).

I2I. "O Aegypte, Aegypte, religionum tuarum solae supererunt fabulae eaque incredibiles posteris tuis solaque supererunt uerba lapidibus incisa tua pia facta narrantibus et inhabitabit Aegyptum. / Quid fles, o Asclepi? I.” El original latino se tomó de la versión de Les Belles Lettres, I992, 327. La traducción es mía. 
Dentro del Corpus hermeticum encontramos una serie de diálogos que se realizan entre Tat y el Trimegisto. En éstos encontramos la ternura de las enseñanzas de un amoroso padre a un hijo, aquí se nos develan muchos secretos acerca de la formación de los hombres. En el diálogo titulado La crátera o mónada, la lección resulta muy útil para entender la fuente del dolor de Polifilo. En éste se explica cómo el dios de Hermes creó por medio de la palabra todas las cosas y todos los seres que existen, y lo ha realizado por bondad, ya que este dios, que no es comparable ni con el aire ni con el fuego, ni nada de lo que existe, es ante todo bueno. Y como es bueno no quiso este bello don para él sólo y trajo al hombre a su hermosa obra: la Tierra. ${ }^{\mathrm{I} 2} \mathrm{El}$ hombre a su vez quedó maravillado por la Naturaleza y por su parecido con todo lo divino, y supo ver en su reflejo a su creador. Dios hizo partícipes de la razón a todos los hombres, pero no así de la mente.

¿Por qué motivo entonces, oh padre, no compartió dios la mente con todos ellos?

Lo que quería Tat, hijo mío, es colocar la mente entre las almas, como un premio a conquistar

¿Y dónde la colocó?

Cuando había llenado una amplia crátera, la envió con un heraldo, a quien ordenó hacer la siguiente proclama al ánimo de los hombres: "Sumérgete tú mismo en esta crátera, ya que puedes, si crees que te alzarás de nuevo hacia aquel que te ha enviado la crátera aquí abajo, y si sabes reconocer para qué naciste". ${ }^{23}$

Entonces, quienes presten atención a la proclama y se sumerjan en la crátera se harán partícipes del conocimiento. Pero aquellos que hagan caso omiso del mensaje serán sólo personas de razón, pues no tienen el don de la mente y tampoco conocen el propósito que les trajo a la vida ni por obra de quién. Estos hombres sienten y se comportan como los animales irracionales, no admiran las cosas dignas de contemplación, se abandonan a las pasiones y apetitos del

I22. "terram quoque ornatu quodam divini operis exornare voluit", en la traducción de Ficino.

I23. "Cur, o pater, non omnibus deus mente comunicauit/Quoniam uoluit tat, o fili, in medio tanquam certamen premiumque animarum proponere/Ubinam hac locauit?/Cum craterem patulum hac implesset, praecone misit, iubens talia quaedam animis hominum nunciare: Mergat se ipsam in hanc pateram, quaecumque potest. Quae uide licet credit craterem animam ad eum qui demiserat redditurum. Quaeue finem noscit, cuius gratia nata fuerit."

El texto latino se tomó de la traducción de Ficino en la edición Mercuri Trimegisti Liber de Potestate et Sapientia Dei, publicada en 1493 en Venecia en la imprenta de Damianum de Mediolano, lib. IV, s.n.p. 
cuerpo. Pero aquellos que poseen la mente son más inmortales que mortales, pues han logrado entender todas las cosas: las de la tierra, las del cielo e incluso las que se hallan más allá. ${ }^{124}$

Para acceder al conocimiento hace falta un buen corazón, un corazón valiente, un corazón armado. Polifilo se duele por la ignorancia de su tiempo, que se ve reflejada en los pobres corazones de sus coetáneos. Polia, el objetivo de su búsqueda, es la mente y el sueño el acto de sumergirse con valor en la crátera. Si resulta arriesgada esta afirmación, tal vez ayude señalar lo que entendía Polifilo por ignorancia, tema del séptimo libro hermético, que trata sobre el mayor mal de los hombres: ${ }^{125}$ ignorar a dios.

"Caigan mortales: hombres embriagados, bebieron la doctrina de la ignorancia pura. Como no podéis soportarla, vomítenla. Vivan sobrios: miren con los ojos de la mente. Pues si no todos pueden, al menos quienes puedan: que lo hagan. La peste de la ignorancia inunda toda la tierra y corrompe al alma, prisionera de las cadenas del cuerpo." ${ }^{\text {I26 }}$

$Y$ añade Ficino en su traducción una frase que no encontramos en el griego original: "¡Respiren!, ya respiren: recurran a la fuente de la vida."

Polifilo inhala el aire a su alrededor con la misma desesperación que contagia el imperativo de Ficino, en busca del alivio. Sabía que los hombres ya sólo veían con los ojos y no sentían con el corazón y la mente. El corazón de Polifilo está enfermo a causa de la ignorancia de los hombres que ya no reconocen quién los hizo, por qué están aquí y a dónde van. Para entender la profundidad de esta afirmación sólo falta volver al principio, a la primera verdad que le es develada a Hermes: la creación.

La Mente, el primer dios, es padre de la Palabra, y la sustancia acuosa, habiendo recibido a la Palabra, se transformó en todas las cosas. Entonces, la primera Mente dio nacimiento a otra Mente, hacedora de cosas, ella hizo de fuego y de agua siete administradores, ${ }^{\mathrm{I} 27}$ que rodean con sus órbitas el mundo percibido por los sentidos y definen el Destino. También dio nacimiento al

I24. Según el libro IV del Corpus hermeticum.

I25. "Quod summum Malum Hominibus ignorare deus", lib. VII del Corpus hermeticum.

I26. "Vo ruitis mortales: ebriique merum ignorantiae combibistis. Cum id ferre nequearis: uomite. Vivite sobrii: oculis menti inspicite. Quod si minus potestis omnes saltem qui possunt : id agant. Ignorantiae pestis omnem terram subuertit animamque corrumpit corporis uinclis iclusam/Respirate iam respirate: ad fontem vitae recurrite." El texto latino, traducción de Ficino, fue tomado de la edición veneciana de I 493.

I27. Los planetas. 
Hombre, semejante a su padre, y el dios entregó al ser humano todas las cosas que habían sido hechas. El Hombre habitaba en la más alta esfera con su padre y sus hermanas. Habiendo observado todas las cosas desde arriba, quiso él también hacer y su padre le dio permiso. Todos los administradores le dieron una parte de su poder y se deleitaban con él. Entonces el Hombre quiso atravesar todas sus órbitas. Cuando llegó hasta la última contempló a la Naturaleza. La Naturaleza lo contempló a él y al ver la belleza del dios en su rostro, le sonrió. El Hombre al ver su reflejo en el agua y su sombra en la tierra, la amó. El Hombre quiso vivir en ella, y la Naturaleza lo tomó, lo envolvió en su abrazo y se mezclaron en uno solo, pues estaban enamorados el uno del otro. El Hombre asumió entonces un alma mortal, y como ya tenía el alma inmortal que su padre le había regalado, gozó de una naturaleza doble. Por eso, el Hombre de gran fuerza ascenderá las siete esferas celestes a su muerte y vivirá con su padre, su alma inmortal. Pero, en cambio, si ha sido necio o malvado, caerá en un fuego tortuoso. ${ }^{\mathrm{I} 28}$

Entonces la ignorancia consiste en no conocer este origen del Hombre y este primer gran amor que sintió por la Naturaleza; no reconocer su rostro en las aguas y no comprender que tras la muerte le espera una vida inmortal. El acceso a esa vida sólo se encuentra mediante el conocimiento que, a su vez, sólo se obtiene con un corazón valiente. Por eso Polifilo llora por su amada maltratada, por su padre olvidado y los corazones cobardes de tantos otros hombres. Él encontrará a su amada dentro del sueńo, pero despertará para descubrir que el resto del mundo la ha olvidado.

El sentimiento de Polifilo era común a los hombres de su época. Gracias a poetas como Petrarca y Dante Alighieri la antigüedad clásica comenzó a recobrar su valor perdido. Roma, la ciudad que vivía sobre las ruinas de la capital del imperio, comenzó a mirar hacia atrás, a desempolvar piezas y a redescubrir tesoros. La idea de la decadencia romana semejante a un gran cuerpo enfermo se vivía cotidianamente por sus calles. Por ejemplo, en I 430 Poggio Bracciolini pensaba:

Roma, saqueada de toda majestad, yace postrada a modo de gigantesco cadáver putrefacto y por todas partes corroído. ¿Qué cosa jamás ver el mundo más grande 
con innumerables edificios urbanos, templos, pórticos, termas, teatros, acueductos, puertas hechas con arte, palacios abatidos, y de tantas magnificencias casi nada o poco sobrevivir? ${ }^{129}$

Así también Flavio Biondo escribió en I444 su libro titulado Roma instaurata, en el que proponía al papa Eugenio IV rescatar de la ruina a la ciudad que una vez había sido capital de un gran imperio. El dolor de Polifilo es la misma melancolía de Biondo, ocasionado por el mundo que le rodea en el que la antigua sabiduría ha sido olvidada. Es a causa del hermetismo del discurso que no se ilustra el pasaje del coloso yacente, del que deducimos el verdadero mal, porque así el secreto está mejor guardado. Además, un dolor como el suyo no puede expresarse en un simple dibujo.

El mal de Polifilo no es difícil de diagnosticar, pero tampoco se cura fácilmente, y no sólo se sufrió en el siglo Xv. Por suerte, los que todavía vemos con el corazón la sonrisa de nuestra amada Naturaleza seguimos en busca del remedio a tantos suspiros, porque al final del día la Roma instaurada es un proyecto que hasta hoy sigue siendo un sueño, pues el verdadero peregrino nunca deja de buscar.

\section{Conclusiones}

En I8 de abril de I485, en la Via Appia, cerca de la iglesia de Santa Maria Nuova en Roma, se encontró un sarcófago de mármol con la inscripción "Julia, hija de Claudio". En su interior se hallaba el cuerpo de una joven de alrededor de quince años, que por su aspecto se aseguró debía haber vivido en la antigua Roma de Cicerón. A su belleza se le añadía el perfecto estado de conservación en el que se encontraba, se dijo que incluso sus mejillas parecían sonrosadas. En seguida la noticia corrió por todas partes, y pronto las multitudes se juntaban para observarla. Los artistas asistían para retratarla, ya que su belleza

I29. "Roma, spoliata d'ogni masta, giace prostata a guisa di gigantesco cadavere putrefatto e d'ogni parte corroso. Che cosa mai vide il mondo di più grande, degli innumerevoli edifici urbani, templi, portici, terme, teatri, acquidotti, porti artifatti, palazzi adesso abbattuti, e di tante magnificenze quasi niente o poco sopravivere?" Poggio Bracciolini, De varietate fortunae, 6.7. Véase Lefaivre, Leon Battista Alberti's Hypnerotomachia Poliphili, 36-ss. 
maravillosa era aquella de otra época: una mejor. Nada igual podía existir en el mundo moderno. ${ }^{130}$

En este ambiente de añoranza del pasado se publicó el libro más bello del Renacimiento: la Hypnerotomachia Poliphili. Su realidad atrapada en sus hermosas xilografías, y su rico texto, embellecido con su lenguaje, mezcla de términos griegos y latinos, que le brindan una profundidad única, es aquella de los sabios espíritus humanistas del siglo XVI. Al repasar su vida a través de sus ediciones, traducciones, interpretaciones y reinterpretaciones podemos entender su importante papel en las artes, la arquitectura y la literatura. El primer apartado de este texto ahonda en el devenir de Polifilo, el que sus creadores no hubieran adivinado para él. En diferentes tiempos y lugares su suerte ha cambiado, ha sido adorado por sus ilustraciones y vituperado por ellas, criticado por el mismo lenguaje que también alaban otros, pero lo cierto es que en ningún momento ha perdido fama. Su vida se extiende desde las obras arquitectónicas y escultóricas de su tiempo, hasta el trabajo de los surrealistas de principios del siglo pasado y las fantasías eróticas de nuestros días.

La narración de la Hypnerotomachia responde a una larga tradición de textos literarios y filosóficos que elaborados a manera de sueño retrataban profundas revelaciones. El peregrinar de Polifilo a lo largo de estos paisajes, imposibles en la realidad, es el anhelo de un mundo pasado. Ya sea el antiguo Egipto, o el amplio Imperio romano, la melancolía de los siglos XV y xvi llevaba su mirada al pasado perdido. En jardines como el construido por Pier Francesco Orsini, vemos este mundo de sueños traído a la realidad, en consonancia con el sentimiento común a su época, compartido por poetas y artistas. También en otros jardines podemos adivinar esta misma búsqueda, como en la Villa Lante en Bagnaia o en el Mediceo Jardín del Pratolino. También en las ricas decoraciones de palacios, como el perteneciente a la familia Farnese en Caprarola o en el Castello Sforza en Milán. El segundo apartado consiste en, además de resaltar la importancia del sueño en las creaciones polifilescas, brindar una nueva interpretación iconográfica al Ninfeo de Bomarzo, destacando la importancia del sentido del tacto en él y su posible representación desaparecida.

Finalmente, la tercera parte de este estudio espera dilucidar la verdadera belleza de Polifilo, la que se encuentra atrapada en su profunda filosofía hermética. Esta propuesta pone de manifiesto la relación entre la Hypnerotoma-

I30. Jacob Burckhardt, The Civilization of the Renaissance in Italy (Viena y Londres: The Phaidon Press/George Allen \& Unwin Ltd., 1944), 97. 
chia, el Timeo de Platón y los textos del Corpus hermeticum. Esto, a partir de los textos en su lengua original, salvo el Timeo de Platón que se tomó de la versión de Marsilio Ficino, misma que fue ampliamente difundida en Italia durante los siglos XV y XVI, y cuya versión resulta afín a los intereses renacentistas. De esta manera se procuró que los textos citados fueran ediciones contemporáneas, con verdaderas posibilidades de haber influido los unos en los otros, y de manera particular en las formas del arte renacentista exploradas en este trabajo: los jardines.

El espacio de estas páginas es apenas suficiente para emprender la búsqueda de Polifilo. Lo cierto es que con el pasar de los siglos las veredas del jardín de Polifilo han encontrado innumerables bifurcaciones. Los atentos lectores de su sueño no pueden conocer su pasión sin enamorarse también de Polia, de ahí los numerosos peregrinos construyendo paisajes de sueño. Gracias a la narración de su enamorado, Polia ha conservado su hermosa figura aún dentro de su sarcófago de mármol, esperando salir de su olvido bajo tierra para seguir atrayendo a las multitudes con su perenne belleza. \$ 